\title{
System ochrony zdrowia w Polsce - wybrane zagadnienia
}

\begin{abstract}
Healthcare system in Poland - selected issues: The article provides an overview of the healthcare policy in Poland with particular emphasis on the health care. In the first section the author looks at the background information about tasks and aims of the healthcare system. In the second section he presents the facts about health of the Polish society and describes characteristics of six elements of the healthcare system, i.e. human resources, delivery of healthcare services, health information systems, access to medicines, financing, and leadership and governance.
\end{abstract}

Słowa kluczowe: $\quad$ system ochrony zdrowia w Polsce, kadry medyczne, system finansowania opieki zdrowotnej

Keywords: healthcare system in Poland, medical personnel, healthcare financing

* Doktor nauk o zdrowiu, adiunkt w Szkole Zdrowia Publicznego Centrum Medycznego Kształcenia Podyplomowego, specjalista ds. społecznych w BAS; e-mail:wojciech.zgliczynski@sejm.gov.pl.

\section{Wstęp}

System ochrony zdrowia w definicji Światowej Organizacji Zdrowia (WHO) to zespół wszystkich organizacji i instytucji, zarówno publicznych, jak i prywatnych, oraz wszelkich zasobów, które służą poprawie, zachowaniu lub przywracaniu zdrowia, niezależnie od otoczenia politycznego i instytucjonalnego, w jakie ów system jest wpisany. Systemy zdrowotne świadczą usługi dla jednostek i populacji oraz prowadzą działania we współpracy z innymi sektorami, aby modyfikować społeczne, środowiskowe i ekonomiczne uwarunkowania zdrowia ${ }^{1}$.

Współcześnie systemy ochrony zdrowia mają kluczowe znaczenie dla funkcjonowania społeczeństw. Od ich sprawności zależy nie tylko stan zdrowia danej

1 M. Piotrowicz, D. Cianciara, M.J. Wysocki, Systemy zdrowotne dla zdrowia i dobrobytu - Karta z Tallina, „Przegląd Epidemiologiczny” 2009, nr 63, s. 321-324. 
populacji i możliwości jej reprodukowania, ale także spójność społeczna i możliwości rozwoju społeczno-gospodarczego.

Systemy ochrony zdrowia angażują znaczną liczbę zasobów ludzkich i finansowych. Dla przykładu w państwach należących do Organizacji Współpracy Gospodarczej i Rozwoju (OECD) przeciętne zatrudnienie w systemie ochrony zdrowia wynosi $10 \%$ pracujących w gospodarce, a przeciętnie wydatki bezpośrednie wynoszą blisko $10 \% \mathrm{PKB}^{2}$. Co istotne, udział ten stale wzrasta wraz z postępującymi przemianami demograficznymi i epidemiologicznymi, a także rozwojem technologii medycznych i zwiększaniem się świadomości i oczekiwań ludności co do podnoszenia standardu opieki. Znaczenie ma również komercjalizacja, a także medykalizacja rozumiana jako proces, w którym coraz częściej niektóre stany i problemy są traktowane jako kwestie medyczne ${ }^{3}$.

Celem opracowania jest przedstawienie elementów systemu ochrony zdrowia w Polsce, ze szczególnym uwzględnieniem systemu opieki zdrowotnej. W tekście przedstawiono też zarys sytuacji zdrowotnej społeczeństwa, będącego adresatem działań systemu ochrony zdrowia. Ponadto w opracowaniu, posługując się ujęciem zaproponowanym przez WHO, zaprezentowano podstawowe elementy systemu opieki zdrowotnej w Polsce, tj. zasoby kadrowe, dostarczanie świadczeń zdrowotnych, system informacji zdrowotnej, dostęp do produktów i technologii medycznych, system finansowania oraz przywództwo i zarządzanie ${ }^{4}$.

Podstawowym źródłem prezentowanych danych są opracowania Głównego Urzędu Statystycznego (GUS), WHO, OECD oraz Komisji Europejskiej.

\section{Systemy ochrony zdrowia}

Głównym celem systemów ochrony zdrowia jest zapewnienie bezpieczeństwa zdrowotnego. Cel ten realizowany jest poprzez zaspokajanie potrzeb zdrowotnych, które można podzielić na potrzeby indywidualne oraz potrzeby zbiorowe. Indywidualne potrzeby zdrowotne to potrzeby wynikające z chorób, niedomagań, wypadków, czyli tzw. wyrażone potrzeby zdrowotne (choć system powinien brać pod uwagę istnienie również tzw. rzeczywistych potrzeb zdrowotnych, nie zawsze ujawniających się dostatecznie wcześnie, i zaspokajać je z własnej inicjatywy). Z kolei zbiorowe potrzeby zdrowotne obejmują warunki życia, pracy, zamieszkania, odżywiania, wypoczynku, a nawet chorowania i wszelkie inne aspekty życia zbiorowego, które minimalizują, jeśli nie eliminują, jakiekolwiek ryzyko utraty zdrowia 5 .

2 Health at a Glance 2017: OECD Indicators, OECD 2017, https://dx.doi.org/10.1787/ health_glance-2017-en [dostęp: 7 grudnia 2018 r.].

${ }^{3}$ J. Kłos, M. Gromadecka-Sutkiewicz, M. Zysnarska, Medykalizacja - wyzwanie XXI wieku, „Hygeia Public Health” 2014, nr 49(3), s. 382-388.

${ }^{4}$ Monitoring the building blocks of health systems: a handbook of indicators and their measurement strategies, WHO, 2010.

${ }^{5}$ J. Leowski, Polityka zdrowotna a zdrowie publiczne, CeDeWu, Warszawa 2010, s. 71-72. 
Systemy ochrony zdrowia w poszczególnych państwach różnią się w zależności od regionu oraz ekonomicznego, politycznego i historycznego kontekstu, w którym funkcjonują. Mimo występujących różnic w systemach ochrony zdrowia, ze względu na funkcje i obszar działania można (za WHO) wyróżnić cztery elementy, tj. opiekę zdrowotną, zapobieganie chorobom, promocję zdrowia oraz międzysektorową współpracę na rzecz zdrowia ${ }^{6}$. Tym elementom odpowiadają określone działania. W uproszczeniu opieka zdrowotna to świadczenie usług dla jednostek w ramach medycyny leczniczej i medycyny naprawczej. Zapobieganie chorobom i promocja zdrowia to świadczenie usług dla populacji, w tym ochrona przed chorobami; zagrożeniami środowiska przyrodniczego i środowiska pracy czy też zagrożeniami wynikającymi z niekorzystnych warunków społecznych. Z kolei międzysektorowa współpraca na rzecz zdrowia to działania $\mathrm{w}$ różnych sektorach $\mathrm{w}$ celu modyfikacji społecznych, środowiskowych i ekonomicznych uwarunkowań zdrowia. Istnieje powszechne przekonanie, że wymienione cztery elementy są równoważne. Niemniej daje się zaobserwować tendencję do zawężania problematyki systemów ochrony zdrowia do problematyki systemów opieki zdrowotnej ${ }^{7}$.

Cel systemu ochrony zdrowia, jakim jest zapewnienie bezpieczeństwa zdrowotnego, jest celem ogólnym. W rzeczywistości przed systemami ochrony zdrowia stawiane są też inne cele. Przykładem są cele w ujęciu WHO, tj. poprawa stanu zdrowia, w tym ogólna poprawa stanu zdrowia ludności, oraz niwelowanie nierówności w zdrowiu; reagowanie na oczekiwania obywateli; zapewnienie finansowej ochrony przed ponoszeniem nadmiernych kosztów związanych ze złym stanem zdrowia oraz poprawa efektywności systemu ${ }^{8}$.

Współczesne systemy ochrony zdrowia stoją w obliczu wielkich wyzwań związanych między innymi ze starzeniem się społeczeństwa, wzrostem zapotrzebowania na świadczenia, kosztami technologii medycznych, wzrostem oczekiwań społecznych oraz z nierównościami. Wyzwania te występują w zakresie wszystkich elementów składających się na system ochrony zdrowia, tj. zasobów kadrowych, dostarczania świadczeń zdrowotnych, systemów informacji zdrowotnej, dostępu do usług zdrowotnych, sposobów finansowania oraz przywództwa i zarządzania.

\section{Sytuacja zdrowotna społeczeństwa polskiego}

Systemy ochrony zdrowia powinny być dostosowane do potrzeb zdrowotnych konkretnej populacji, które w istotnym stopniu wynikają z jej sytuacji zdrowotnej.

\footnotetext{
6 M. Piotrowicz, D. Cianciara, M.J. Wysocki, Systemy zdrowotne, op. cit., s. 321-324.

7 A. Wojtczak, Aktualne wyzwania zdrowotne społeczeństw, CeDeWu, Warszawa 2018.

8 Monitoring the building blocks of health systems, op. cit.
} 
W 2016 r. przeciętna prognozowana długość życia w chwili urodzenia w Polsce wynosiła 78 lat (82 lata dla kobiet i 73,9 lata dla mężczyzn), przy przeciętnej dla państw UE wynoszącej 81 lat (83,6 lata dla kobiet i 78,2 lata dla mężczyzn). W zakresie przeciętnej spodziewanej długości życia istniały jednak duże różnice w zależności od wykształcenia oraz płci. W przypadku osób 30-letnich różnica między osobami z wykształceniem wyższym i podstawowym co do spodziewanej dalszej długości życia wynosiła 12,0 lat w grupie mężczyzn i 5,1 lat w grupie kobiet, przy różnicach przeciętnie w państwach UE wynoszących odpowiednio 7,7 lat w grupie mężczyzn i 4,1 lat w grupie kobiet ${ }^{9}$. Warto odnotować, że między 2016 r. i 1950 r. przeciętna długość życia w Polsce wzrosła o blisko 20 lat (tabela 1).

Tabela 1. Przeciętne trwanie życia w wieku O w latach 1950-2016

\begin{tabular}{|l|c|c|c|c|c|c|c|c|c|}
\hline & $\mathbf{1 9 5 0}$ & $\mathbf{1 9 6 0}$ & $\mathbf{1 9 7 0}$ & $\mathbf{1 9 8 0}$ & $\mathbf{1 9 9 0}$ & $\mathbf{2 0 0 0}$ & $\mathbf{2 0 1 0}$ & $\mathbf{2 0 1 5}$ & $\mathbf{2 0 1 6}$ \\
\hline Ogółem & 58,9 & 67,8 & 70,0 & 70,2 & 70,7 & 73,9 & 76,3 & 77,6 & 77,9 \\
\hline Mężczyźni & 56,1 & 64,9 & 66,6 & 66,0 & 66,2 & 69,7 & 72,1 & 73,6 & 73,9 \\
\hline Kobiety & 61,7 & 70,6 & 73,3 & 74,4 & 75,2 & 78,0 & 80,6 & 81,6 & 81,9 \\
\hline
\end{tabular}

Źródło: GUS, http://demografia.stat.gov.pl/bazademografia/TrwanieZycia.aspx [dostęp: 1 września 2018 r.].

W 2016 r. w populacji ogólnej swój stan zdrowia jako dobry i bardzo dobry oceniało 59\% polskich obywateli, przy czym istniały duże różnice między obywatelami ze względu na poziom zamożności. W przypadku $1 / 5$ populacji, która osiąga najwyższe dochody, wskaźnik ten wynosił $72 \%$, natomiast w przypadku $1 / 5$ populacji osiągającej najniższe dochody - 52\%. Samoocena stanu zdrowia polskiej populacji była znacznie gorsza niż przeciętna w państwach UE, gdzie odsetki te wynosiły odpowiednio $68 \%, 78 \%$ oraz $60 \%$. Samoocena stanu zdrowia była gorsza w starszych grupach wiekowych. W 2015 r. w przypadku osób po 65. roku życia odsetek osób pozytywnie oceniających swoje zdrowie wynosił w Polsce 16,6\% (mężczyźni 18,8\% i kobiety 14,3\%), przy istotnie wyższej średniej dla państw OECD, wynoszącej 44,0\% (mężczyźni 46,6\% i kobiety 41,3\%). Co ważne, w Polsce ograniczenia w wykonywaniu codziennych aktywności zgłaszało 54,3\% osób, które przekroczyły 65 lat $^{10}$.

Samoocena stanu zdrowia znajduje odzwierciedlenie w częstości korzystania z opieki zdrowotnej. Można zauważyć, że w Polsce wraz z wiekiem wyraźnie rośnie odsetek osób chorujących przewlekle i potrzebujących opieki medycznej ${ }^{11}$. Starości nierzadko towarzyszą wielochorobowość, polipragmazja ${ }^{12}$ i dłuższe

${ }^{9}$ Health at a Glance: Europe 2018: State of Health in the EU Cycle, OECD Publishing, Paris 2018, https://doi.org/10.1787/health_glance_eur-2018-en [dostęp: 7 grudnia 2018 r.].

${ }_{10}$ Health at a Glance 2017: OECD Indicators, op. cit.

${ }^{11}$ GUS, Ochrona zdrowia w gospodarstwach domowych w 2016 r., Warszawa 2018.

12 Równoczesne stosowanie wielu (kilku, a nawet kilkunastu) leków; jeden z częstszych błędów w postępowaniu medycznym, prowadzacy m.in. do znacznego zwiększenia występo- 
okresy rekonwalescencji ${ }^{13}$. Tym samym rosną też wyraźnie przeciętne wydatki na świadczenia zdrowotne ${ }^{14}$. Nie należy wiązać wzrostu zapotrzebowania na świadczenia zdrowotne wyłącznie z wiekiem. Stan zdrowia, a zwłaszcza skala występowania chorób przewlekłych mogą być w istotnym stopniu modyfikowane poprzez działania z zakresu promocji zdrowia i profilaktyki. Działania te można ukierunkować między innymi na zmniejszanie popularności palenia tytoniu, zmniejszanie konsumpcji alkoholu, poprawę diety i zwiększanie aktywności fizycznej. Nie bez znaczenia są również działania ukierunkowane na poprawę warunków środowiskowych, takich jak zanieczyszczenie powietrza.

Istotny wpływ na funkcjonowanie danego państwa, w tym systemu ochrony zdrowia, ma struktura demograficzna społeczeństwa. Według ostatniej prognozy demograficznej GUS ${ }^{15}$ populacja Polski w 2013 r. liczyła 38,5 mln osób, przy czym udział grupy w wieku do 18. roku życia (wiek przedprodukcyjny) w populacji wynosił 18,2\%, grupa w wieku aktywności zawodowej (produkcyjny mobilny i niemobilny) stanowiła 63,4\%, a udział osób w wieku poprodukcyjnym wynosił 18,4\%. Prognoza GUS wskazuje, że w 2050 r. populacja ogólna zmaleje do 33,9 mln, odsetek ludności w wieku przedprodukcyjnym spadnie do $14,6 \%$, natomiast odsetek ludności w wieku poprodukcyjnym wzrośnie do $36,5 \%$ (tabela 2). Tym samym społeczeństwo polskie z jednego z demograficznie najmłodszych stanie się jednym z najstarszych wśród społeczeństw państw UE. Należy dodać, że są to prognozy optymistyczne, nieuwzględniające w pełni emigracji młodych osób po akcesji Polski do Unii Europejskiej w 2004 r. Ta prognoza demograficzna ma istotne znaczenie nie tylko ze względu na spodziewany wzrost kosztów systemu ochrony zdrowia, ale również malejące zdolności ich finansowania.

Główne przyczyny zgonów w Polsce w okresie od 1960 do 2015 r. podlegały wyraźnym zmianom (tabela 3). Należy zwrócić uwagę, że niezmiennie najistotniejszą przyczyną zgonów pozostają choroby układu krążenia, które w 2015 r. odpowiadały za blisko połowę wszystkich zgonów. Mimo że od lat 90. XX wieku natężenie zgonów w powodu chorób układu krążenia w Polsce stopniowo się zmniejszało, to w dalszym ciągu było znacznie częstszą przyczyną zgonów (610 zgonów na 100 tys. mieszkańców) niż przeciętnie w państwach UE (381 zgonów na 100 tys. mieszkańców) ${ }^{16}$. Drugą najczęstszą przyczyną zgonów były choroby nowotworowe, odpowiedzialne za ponad 1/4 zgonów. Co istotne, w tym obszarze nie ob-

wania niezamierzonych interakcji leków, często groźnych dla zdrowia lub nawet życia, https:// encyklopedia.pwn.pl [dostęp: 7 grudnia 2018 r.].

${ }_{13}$ Sytuacja zdrowotna ludności Polski i jej uwarunkowania, red. B. Wojtyniak, P. Goryński, Narodowy Instytut Zdrowia Publicznego - Państwowy Zakład Higieny, Warszawa 2016.

${ }^{14}$ Prognoza kosztów świadczeń opieki zdrowotnej finansowanych przez Narodowy Fundusz Zdrowia w kontekście zmian demograficznych w Polsce, NFZ, Warszawa 2015, s. 4.

15 GUS, Prognoza ludności na lata 2014-2050, Warszawa 2014.

${ }^{16}$ Health at a Glance: Europe 2018, op. cit. 
Tabela 2. Prognozowana liczba ludności według ekonomicznych grup wieku

\begin{tabular}{|c|c|c|c|c|c|c|c|c|}
\hline \multirow{2}{*}{ Wiek } & \multicolumn{2}{|c|}{2013} & \multicolumn{2}{|c|}{2020} & \multicolumn{2}{|c|}{2035} & \multicolumn{2}{|c|}{2050} \\
\hline & w tys. & $\%$ & w tys. & $\%$ & w tys. & $\%$ & w tys. & $\%$ \\
\hline Przedprodukcyjny (0-17 lat) & 6995 & 18,2 & 6733 & 17,7 & 5568 & 15,3 & 4963 & 14,6 \\
\hline Produkcyjny mobilny (18-44 lata) & 15338 & 39,8 & 14219 & 37,3 & 10725 & 29,4 & 9331 & 27,5 \\
\hline $\begin{array}{l}\text { Produkcyjny niemobilny } \\
(45-59 / 64 \text { lata) }\end{array}$ & 9084 & 23,6 & 8568 & 22,5 & 9990 & 27,4 & 7252 & 21,4 \\
\hline Poprodukcyjny $60+/ 65+$ lat & 7078 & 18,4 & 8617 & 22,6 & 10193 & 27,9 & 12404 & 36,5 \\
\hline Ogółem & 38495 & 100,0 & 38137 & 1000 & 36476 & م 100 & 33950 & 100,0 \\
\hline
\end{tabular}

Źródło: GUS, Prognoza ludności na lata 2014-2050, Warszawa 2014, s. 148.

serwuje się poprawy, a sytuacja jest wyraźnie gorsza (304 zgony na 100 tys. mieszkańców) niż przeciętna w państwach UE (261 zgonów na 100 tys. mieszkańców) ${ }^{17}$. Wypadki, urazy i zatrucia były przyczyną co 20 zgonu. Mimo notowanej od lat 90. XX wieku poprawy w dalszym ciągu sytuacja w tym zakresie była wyraźnie gorsza (56 zgonów na 100 tys. mieszkańców) niż przeciętna w państwach UE (47 zgonów na 100 tys. mieszkańców) ${ }^{18}$. W przypadku tej grupy zgonów jedną ze składowych były zgony z powodu samobójstw. Warto odnotować, że w Polsce liczba zgonów z powodu samobójstw była wyższa niż liczba zgonów w powodu wypadków drogowych. Co do liczby samobójstw, to była ona wyraźnie wyższa niż przeciętna w państwach UE [ogółem wskaźnik samobójstw w Polsce wynosił 14,2 na 100 tys. mieszkańców (średnia UE - 10,9 na 100 tys.) i był szczególnie wysoki wśród mężczyzn (26,2 na 100 tys. mieszkańców, przy średniej UE wynoszącej 17,9)] ${ }^{19}$, co wskazywało na szerszy problem związany ze stanem zdrowia psychicznego.

Tabela 3. Główne przyczyny zgonów w latach 1960-2015 (w \%)

\begin{tabular}{|l|r|r|r|r|r|r|r|}
\hline \multicolumn{1}{|c|}{ Przyczyna } & $\mathbf{1 9 6 0}$ & $\mathbf{1 9 7 0}$ & $\mathbf{1 9 8 0}$ & $\mathbf{1 9 9 0}$ & $\mathbf{2 0 0 0}$ & $\mathbf{2 0 1 0}$ & $\mathbf{2 0 1 5}$ \\
\hline Choroby układu krążenia & 23,4 & 34,5 & 47,4 & 53,4 & 47,7 & 46,0 & 45,7 \\
\hline Choroby nowotworowe & 8,9 & 13,4 & 16,8 & 19,1 & 23,4 & 25,3 & 26,7 \\
\hline Wypadki, urazy i zatrucia & 4,3 & 6,0 & 7,6 & 7,8 & 7,0 & 6,2 & 5,0 \\
\hline Choroby układu oddechowego & 7,5 & 8,4 & 5,6 & 4,0 & 5,0 & 5,1 & 6,1 \\
\hline Choroby zakaźne i pasożytnicze & 6,9 & 3,9 & 1,6 & 0,8 & 0,6 & 0,7 & 0,5 \\
\hline
\end{tabular}

Źródło: P. Szukalski, Jak umierają Polacy?, „Demografia i Gerontologia Społeczna - Biuletyn Informacyjny” 2013, nr 1, oraz Health at a Glance: Europe 2018: State of Health in the EU Cycle, OECD Publishing, Paris 2018, https://dx.doi.org/10.1787/health_glance-2017-en [dostęp: 7 grudnia 2018 r.].

Należy stwierdzić, że stan zdrowia populacji w Polsce, mimo obserwowanych od lat 90. XX wieku pozytywnych zmian, jest w dalszym ciągu niezadowalający. Mimo wydłużania się przeciętnej długości życia, obserwuje się wysoki odsetek

17 Ibidem

18 Ibidem.

19 Ibidem. 
negatywnych ocen stanu zdrowia, a także wysoki i wzrastający odsetek osób chorujących przewlekle (długotrwałe problemy zdrowotne lub choroby przewlekłe trwające przez 6 miesięcy lub dłużej dotyczyły w 2006 r. 25,5\% populacji, a w 2016 już 34,1\%), co wiązało się ze wzrostem odsetka osób przebywających pod stałą opieką medyczną z 23,7\% w 2006 r. do 36,0\% w 2016 r. $^{20}$. Należy zwrócić uwagę, że zły stan zdrowia jest w istotnym stopniu powiązany z niskim poziomem wykształcenia oraz złą sytuacją materialną. To zjawisko wskazuje na problemy nie tylko w zakresie opieki zdrowotnej, ale również niedostatki związane z promocją zdrowia i profilaktyką.

\section{Personel systemu ochrony zdrowia}

Według WHO dla prawidłowego funkcjonowania systemu ochrony zdrowia konieczne jest zapewnienie właściwej liczby odpowiednio wykwalifikowanych i rozmieszczonych pracowników, przygotowanych do odpowiadania na oczekiwania ludności, oraz pracujących w sposób skuteczny, rzetelny i wydajny. Pracownicy systemu ochrony zdrowia są szczególnym elementem systemu ochrony zdrowia - mają oni zasadniczy wpływ na jego funkcjonowanie, ich pozyskanie i szkolenie jest nie tylko kosztowne, ale też wymaga czasu, a wynagrodzenia tej grupy stanowią zasadniczą część wszystkich kosztów funkcjonowania systemu.

Współcześnie systemy ochrony zdrowia angażują istotną część wszystkich pracowników. Obowiązująca w Polsce klasyfikacja zawodów ${ }^{21}$ wśród specjalistów do spraw zdrowia wymienia 15 zawodów, wraz z kilkudziesięcioma specjalnościami, jakie w tych zawodach można uzyskać. Liczba wszystkich pracowników ochrony zdrowia razem z pracownikami pomocy społecznej stanowiła w Polsce w 2015 r. 5,9\% wszystkich zatrudnionych, co było poniżej średniej dla 34 państw OECD, wynoszącej 10,1\%22.

$\mathrm{Na}$ temat personelu medycznego dostępne są trzy grupy danych, tj. o osobach posiadających prawo wykonywania zawodu medycznego, osobach aktywnych zawodowo (na podstawie rejestrów lekarzy, farmaceutów, pielęgniarek i położnych) oraz osobach pracujących bezpośrednio z pacjentem. Danych na temat osób pracujących w zawodach medycznych, ale nieobjętych obowiązkiem rejestracji, niestety brakuje.

Zgodnie z danymi GUS w 2016 r. liczba pracowników medycznych w Polsce mających prawo wykonywania zawodu wynosiła łącznie 560,2 tys. osób, w tym 288 tys. pielęgniarek, 145 tys. lekarzy, 41,2 tys. lekarzy dentystów, 37 tys. położnych, 34 tys. farmaceutów i 15 tys. diagnostów laboratoryjnych.

20 GUS, Ochrona zdrowia w gospodarstwach domowych w 2016 r., op. cit.

${ }^{21}$ Rozporządzenie Ministra Pracy i Polityki Społecznej z 7 sierpnia 2014 r. w sprawie klasyfikacji zawodów i specjalności na potrzeby rynku pracy oraz zakresu jej stosowania, Dz.U. 2018, poz. 227.

${ }^{22}$ Health at a Glance 2017: OECD Indicators, op. cit. 
Liczba osób mających prawo wykonywania zawodu jest większa niż liczba wykonujących zawód. Obrazują to dane Naczelnej Izby Lekarskiej (NIL). W 2018 r. liczba wszystkich członków Izby wynosiła 188 tys., w tym 146,3 tys. lekarzy i 41,1 lekarzy dentystów ${ }^{23}$. Natomiast liczba lekarzy i lekarzy dentystów wykonujących zawód wynosiła 171,8 tys. osób, w tym 134,8 tys. lekarzy i 36,5 lekarzy dentystów ${ }^{24}$.

Dane najczęściej używane, w tym również w porównaniach międzynarodowych i będące podstawą tej analizy, dotyczą personelu, który pracuje z pacjentami. W przypadku lekarzy, zgodnie z danymi GUS, w 2016 r. pracę z pacjentami wykonywało 91,7 tys. lekarzy, 13,3 tys. lekarzy dentystów, 195,8 tys. pielęgniarek oraz 22,9 tys. położnych. Liczba lekarzy i pielęgniarek w stosunku do liczby ludności na przestrzeni lat, mimo wzrastającego zapotrzebowania na usługi zdrowotne, utrzymywała się na stabilnym poziomie (tabela 4).

Tabela 4. Wybrane grupy pracowników medycznych w Polsce w latach 1990-2016

\begin{tabular}{|c|r|r|r|r|r|r|r|}
\cline { 2 - 7 } \multicolumn{1}{c|}{} & $\mathbf{1 9 9 0}$ & $\mathbf{1 9 9 5}$ & $\mathbf{2 0 0 0}$ & $\mathbf{2 0 0 5}$ & $\mathbf{2 0 1 0}$ & $\mathbf{2 0 1 5}$ & $\mathbf{2 0 1 6}$ \\
\hline Lekarze & 81,6 & 89,4 & 85,0 & 81,6 & 83,2 & 88,4 & 91,7 \\
\hline na 10 tys. ludności & 21,4 & 23,2 & 22 & 21,4 & 21,6 & 23,0 & 23,9 \\
\hline Lekarze dentyści & 18,2 & 17,8 & 11,8 & 12,2 & 12,5 & 12,6 & 13,3 \\
\hline na 10 tys. ludności & 4,8 & 4,6 & 3 & 3,2 & 3,3 & 3,3 & 3,5 \\
\hline Pielęgniarki & 207,8 & 211,6 & 189,6 & 194,2 & 200,8 & 197,4 & 195,8 \\
\hline na 10 tys. ludności & 54,4 & 54,8 & 49,1 & 50,9 & 52,1 & 51,4 & 51 \\
\hline Położne & 24,0 & 24,4 & 22,0 & 21,0 & 22,6 & 22,5 & 22,9 \\
\hline na 10 tys. ludności & 6,3 & 6,3 & 5,7 & 10,7 & 11,4 & 11,3 & 11,5 \\
\hline
\end{tabular}

Źródło: „Rocznik Statystyczny Rzeczypospolitej Polskiej” 2017 i wcześniejsze, GUS.

\section{Lekarze i lekarze dentyści}

Liczba lekarzy w Polsce w odniesieniu do liczy mieszkańców była najniższa w krajach UE. W 2016 r. liczba lekarzy w przeliczeniu na 1000 mieszkańców wynosiła w Polsce 2,4, przy średniej UE - 3,6. Było to również wyraźnie mniej niż w innych państwach naszego regionu, np. Niemiec $(4,2)$, Czech $(3,7)$, Słowacji $(3,5)$ i Węgier $(3,2)^{25}$. Warto podkreślić, że wskaźnik dla Polski w ciągu ostatnich kilkunastu utrzymuje się na stabilnym poziomie, w odróżnieniu do wielu innych państw, w których wskaźnik ten uległ wyraźnemu zwiększeniu.

Poważnym problemem jest proces starzenia się tej grupy zawodowej oraz nasilające się zjawisko tzw. luki pokoleniowej. Analiza struktury wiekowej grup

${ }^{23}$ Dane statystyczne NIL, http://www.nil.org.pl/rejestry/centralny-rejestr-lekarzy/informacje-statystyczne [dostęp: 1 września 2018 r.].

${ }^{24}$ Poza lekarzami i lekarzami dentystami w rejestrach NIL są również osoby, które mają zarówno tytuł zawodowy lekarza, jak i lekarza dentysty.

${ }^{25}$ Health at a Glance: Europe 2018, op. cit. 
lekarzy i lekarzy dentystów w statystykach NIL wskazuje, że 1/5 lekarzy i 11/4 lekarzy dentystów ma mniej niż 35 lat, a 50. rok życia przekroczyła $1 \frac{1}{2}$ praktykujących w Polsce lekarzy i 2 /5 lekarzy dentystów.

Stosunkowo mała liczba lekarzy sprawia, że są oni mocno obciążeni pracą. W 2016 r. przeciętna liczba konsultacji przypadających na jednego lekarza w Polsce w ciągu roku wynosiła 3104, czyli znacznie powyżej średniej UE, która wynosiła $2147^{26}$. Należy zwrócić uwagę, że czas pracy lekarzy w Polsce często przekraczał przyjęte normy ${ }^{27}$.

Istotne z punktu widzenia bezpieczeństwa populacji jest zapewnienie równomiernego rozmieszczenia personelu. Rozmieszczenie lekarzy na terytorium Polski nie jest równomierne. Według informacji Banku Danych Lokalnych GUS w 2016 r. liczba lekarzy na 10 tys. mieszkańców, wynosząca ogółem w Polsce 24, była najmniejsza w województwie wielkopolskim, gdzie wynosiła 16 , natomiast największa w województwach łódzkim i mazowieckim, gdzie wyniosła po $28^{28}$.

Dla właściwego funkcjonowania systemu konieczne jest odpowiednie przeszkolenie lekarzy. Według danych GUS w 2016 r. specjalizację II stopnia i tytuł specjalisty miało 60888 osób, tj. 66,4\% pracujących lekarzy. Kluczową rolę w systemie ochrony zdrowia pełnią lekarze opieki podstawowej. Pełnią oni zazwyczaj funkcję „punktu wejścia” do systemu opieki zdrowotnej i kierują w razie potrzeby pacjenta do lekarzy specjalistów. Są oni również odpowiedzialni za wiele świadczeń profilaktycznych, takich jak badania przesiewowe i szczepienia"29. Jednym z problemów systemu opieki zdrowotnej w Polsce jest stosunkowo niewielki odsetek lekarzy opieki podstawowej (17\%), co wyraźnie odbiega od średniej dla krajów UE, wynoszącej w 2016 r. 29\%, w tym od takich państw, jak np. Francja (46\%) i Finlandia (37\%), Belgia (37\%) ${ }^{30}$.

Deficyt lekarzy w Polsce pogłębiany jest przez emigrację. Brakuje danych na temat dokładnej liczby polskich lekarzy, którzy wyjechali za granicę. Według NIL w 2015 r. zaświadczenia stwierdzające posiadanie formalnych kwalifikacji zawodowych, co nie jest równoznaczne $\mathrm{z}$ wyjazdem do pracy za granicę, wydano 9337 lekarzom ubiegającym się o uznanie kwalifikacji w innych krajach UE, co stanowiło 7\% wykonujących zawód.

Państwo polskie poprzez system kształcenia i szkolenia ma istotny wpływ na liczbę lekarzy oraz kierunki podyplomowego kształcenia medycznego. Mi-

26 Ibidem.

27 NIK, „Zatrudnienie w samodzielnych publicznych zakładach opieki zdrowotnej”, informacja o wynikach kontroli, nr ewid. 41/2015/P/14/065/KZD.

28 Bank Danych Lokalnych GUS, https://bdl.stat.gov.pl/BDL/start [dostęp: 1 września 2018 r.].

29 OECD/European Observatory on Health Systems and Policies, Polska: Profil systemu ochrony zdrowia 2017, State of Health in the EU, OECD Publishing, Paris/European Observatory on Health Systems and Policies, Brussels 2017.

30 Health at a Glance: Europe 2018, op. cit. 
nister Zdrowia co roku ustala limity przyjęć na studia na kierunku lekarskim i lekarsko-dentystycznym, a także liczbę miejsc rezydenckich w konkretnych specjalizacjach dla lekarzy i lekarzy dentystów, którzy rozpoczną specjalizację.

Tabela 5. Limity przyjęć na studia na kierunek lekarski w latach 2008-2018

\begin{tabular}{|c|c|c|c|c|c|c|c|c|c|c|c|}
\hline \multirow[b]{2}{*}{ 훙 } & \multicolumn{2}{|c|}{ Ogółem } & \multicolumn{3}{|c|}{$\begin{array}{l}\text { Jednolite stacjonarne } \\
\text { (w tym cudzoziemcy) }\end{array}$} & \multicolumn{3}{|c|}{$\begin{array}{c}\text { Jednolite } \\
\text { niestacjonarne }\end{array}$} & \multicolumn{3}{|c|}{$\begin{array}{c}\text { Studia w języku innym } \\
\text { niż polski }\end{array}$} \\
\hline & 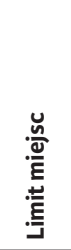 & 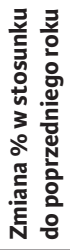 & 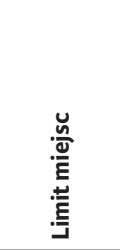 & 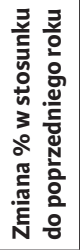 & 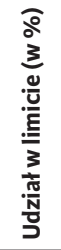 & 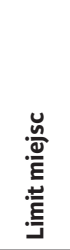 & 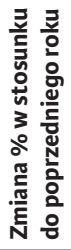 & 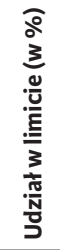 & 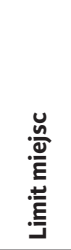 & 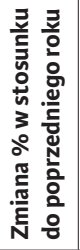 & 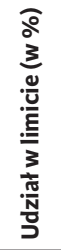 \\
\hline 2008 & 3402 & 5,9 & $2774(84)$ & 2,9 & 81,5 & 628 & 21,2 & 18,5 & - & & - \\
\hline 2009 & 4797 & 41 & $2815(73)$ & 1,5 & 58,7 & 763 & 21,5 & 15,9 & 1219 & & 25,4 \\
\hline 2010 & 4931 & 2,8 & $3023(81)$ & 7,4 & 61,3 & 765 & 0,3 & 15,5 & 1143 & $-6,2$ & 23,2 \\
\hline 2011 & 5059 & 2,6 & $3053(83)$ & 1 & 60,3 & 769 & 0,5 & 15,2 & 1237 & 8,2 & 24,5 \\
\hline 2012 & 5202 & 2,8 & $3165(79)$ & 3,7 & 60,8 & 749 & $-2,6$ & 14,4 & 1288 & 4,1 & 24,8 \\
\hline 2013 & 4731 & $-9,1$ & $2850(74)$ & -10 & 60,2 & 689 & -8 & 14,6 & 1192 & $-7,5$ & 25,2 \\
\hline 2014 & 5510 & 16,5 & $3194(61)$ & 12,1 & 58,0 & 865 & 25,5 & 15,7 & 1451 & 21,7 & 26,3 \\
\hline 2015 & 6188 & 12,3 & $3589(60)$ & 12,4 & 58,0 & 1048 & 21,2 & 16,9 & 1551 & 6,9 & 25,1 \\
\hline 2016 & 7100 & 14,7 & $4191(69)$ & 16,8 & 59,0 & 1168 & 11,4 & 16,4 & 1741 & 12,2 & 24,5 \\
\hline 2017 & 7587 & 6,9 & $4449(81)$ & 6,2 & 58,6 & 1273 & 8,9 & 16,8 & 1865 & 7,1 & 24,6 \\
\hline 2018 & 7846 & 3,4 & $4678(87)$ & 5,1 & 59,6 & 1277 & 0,3 & 16,3 & 1891 & 1,4 & 24,1 \\
\hline
\end{tabular}

Źródło: na podstawie rozporządzeń Ministra Zdrowia w sprawie limitów przyjęć na studia od 2008 r. do 2018 r.

W okresie od 2008 r. do 2018 r. limit przyjęć na studia na kierunku lekarskim ogółem wzrósł o 130,6\% (tabela 5), a w przypadku studiów lekarsko-dentystycznych o 44,4\%. Należy jednak zwrócić uwagę, że od 2009 r., kiedy wprowadzono taką możliwość, co roku przeciętnie ok. 1/4 miejsc była wykorzystywana do kształcenia studentów w języku innym niż polski i z dużym prawdopodobieństwem można przyjąć, że większość absolwentów tych studiów po uzyskaniu dyplomu nie podejmie pracy w Polsce. Podział limitów między studiami prowadzonymi w języku polskim oraz studiami w innych językach (opłaty za studia obcojęzyczne odpowiadają za blisko połowę dochodów własnych uczelni) powoduje, że możliwości systemu kształcenia nie są w pełni wykorzystywane dla zaspokojenia potrzeb kadrowych krajowego systemu ochrony zdrowia ${ }^{31}$. Zwraca uwagę, że zwiększanie liczby studentów nie odbywało się tylko przez rozwój już istniejących wydziałów lekarskich, ale tworzenie nowych wydziałów i tworzenie nowych uczelni. Dla przykładu w roku akademickim 2006/2007 uprawnienia do prowadzenia studiów na kierunku lekarskim miało 11 uczelni,

31 NIK, „Kształcenie i przygotowanie zawodowe kadr medycznych”, informacja o wynikach kontroli, nr ewid. P/15/060, Warszawa 2016. 
a w 2017/2018 liczba ta wzrosła do 20. Wzrost liczby podmiotów kształcących lekarzy odbywał się, mimo że prowadzenie takich studiów wymaga dużych nakładów finansowych na rozwój infrastruktury dydaktycznej i naukowej, a także bardzo dużej liczby personelu. Taka sytuacja każe postawić pytanie o gwarancję utrzymania jakości kształcenia.

W kształceniu specjalizacyjnym również występowały problemy. Według informacji Ministerstwa Zdrowia w okresie od 2010 do 2014 r. liczba tzw. etatów rezydenckich wynosiła ok. 3 tys., od 2015 r. do 2018 r. ustabilizowała się na poziomie ok. 6 tys. $^{32}$. Mimo to w dalszym ciągu zgłaszano deficyty lekarzy specjalistów, w tym np. geriatrów i anestezjologów. Na brak odpowiedniej liczby specjalistów wpływały także limity miejsc do odbywania specjalizacji oraz brak możliwości zobowiązania każdego z podmiotów mających możliwości prowadzenia takiego kształcenia. Kontrola przeprowadzona przez NIK wskazała, że nie wszystkie przyznane miejsca specjalizacyjne były wykorzystywane. Problem ten dotyczył głównie braku chętnych w specjalizacjach uznanych za deficytowe. NIK zwracał też uwagę na niedostatki procedury określania liczby niezbędnych specjalistów ${ }^{33}$.

\section{Pielęgniarki}

Liczba pielęgniarek w Polsce w odniesieniu do liczby ludności należy do najniższych w krajach UE. Zgodnie z danymi UE w 2016 r. liczba pielęgniarek w przeliczeniu na 1000 mieszkańców wyniosła w Polsce 5,2, przy średniej dla UE - 8,4. Liczba ta była wyraźnie niższa niż np. w Danii $(16,9)$, Niemczech $(12,9)$, Czechach $(8,1)$, na Litwie $(7,7)$ i Węgrzech $(6,4)^{34}$.

Rozmieszczenie terytorialne pielęgniarek i położnych wskazuje na występowanie różnic między województwami. Zgodnie z danymi Banku Danych Lokalnych GUS w 2016 r. liczba pielęgniarek i położnych pracujących wg podstawowego miejsca pracy wynosząca dla Polski 57 na 10 tys. mieszkańców, była najmniejsza w województwie wielkopolskim, gdzie wynosiła 44, natomiast największa w województwach podkarpackim i świętokrzyskim, gdzie wynosiła $66^{35}$.

Mimo występujących deficytów nie kształci się wystarczającej liczby pielęgniarek - w 2015 r. liczba absolwentów kierunków pielęgniarskich na 100 tys. osób wynosiła w Polsce 32,1 przy średniej OECD - 46,0 $0^{36}$.

W roku 2016 ponad $1 / 3$ pielęgniarek uprawnionych do wykonywania zawodu było w wieku 45-54 lata. Mniej niż 1/10 stanowiły pielęgniarki w wieku poniżej 35 lat. Stale wzrasta liczba pielęgniarek w wieku 65 lat i więcej.

${ }^{32}$ Strona internetowa Ministerstwa Zdrowia, https://www.gov.pl/web/zdrowie/komunikaty-dla-lekarzy-i-lekarzy-dentystow [dostęp: 1 września 2018 r.]

${ }^{33}$ NIK, „Kształcenie i przygotowanie zawodowe kadr medycznych”, op. cit.

${ }^{34}$ Health at a Glance: Europe 2018, op. cit.

${ }^{35}$ Bank Danych Lokalnych GUS, op. cit.

${ }^{36}$ Health at a Glance: Europe 2017, op. cit. 
Zarysowane problemy w zakresie niedostatecznej liczby personelu medycznego, obciążenia pracą, szkolenia kadr i rozmieszczenia przestrzennego wynikają nie tylko z niskiego poziomu finansowania, ale również z niedostatków planowania i zarządzania systemem. Dla przykładu w Polsce w dalszym ciągu brakuje realnego powiązania systemu kształcenia i szkolenia z wynikami oceny potrzeb zdrowotnych społeczeństwa. Mimo deklaracji o znaczeniu podstawowej opieki zdrowotnej nadal brakuje działań służących motywowaniu lekarzy i pielęgniarek do kształcenia w tym kierunku.

\section{Dostarczanie świadczeń zdrowotnych}

Według WHO świadczenia zdrowotne obejmują wszystkie usługi związane z diagnozowaniem i leczeniem chorób oraz promocją, utrzymaniem i przywracaniem zdrowia. Świadczenia powinny być:

- dostosowane do specyficznych potrzeb zdrowotnych i specyficznych cech pacjentów,

- dostępne, czyli udzielane blisko miejsca zamieszkania lub pracy, we właściwym czasie, bez finansowej bariery,

- punktualne, czyli nieodkładane w czasie, udzielane zgodnie z wyznaczoną porą,

- ciągłe, czyli udzielane przez tego samego świadczeniodawcę albo przez świadczeniodawcę mającego dostęp do informacji o poprzednich działaniach, w nieprzerwanym cyklu prowadzącym do osiągnięcia celu zdrowotnego,

- udzielane z poszanowaniem podmiotowości i godności osób korzystających, także z okazywaniem troski o ich potrzeby emocjonalne, zapewniające bezpieczeństwo i w sposób zrozumiały dla pacjenta,

- efektywne, czyli optymalizujące relację między nakładem i efektem, a także przez wybór procedury medycznej oraz ze względu na proporcje stosowania świadczeń zapobiegawczych i leczniczych,

- skuteczne, czyli prowadzące do osiągnięcia celu zdrowotnego, a wybierane na podstawie wiarygodnych dowodów naukowych.

Świadczenie usług zdrowotnych musi uwzględniać wiele zmiennych specyficznych dla danej społeczności. Podkreśla się, że istotne jest dostosowanie wielkości oraz struktury i rozmieszczenia przestrzennego zasobów do wielkości oraz struktury potrzeb zdrowotnych populacji.

\section{Infrastruktura}

Dostarczanie świadczeń zdrowotnych odbywa się w głównej mierze w ramach infrastruktury systemu ochrony zdrowia. Ze względu na rodzaj świadczonych usług zdrowotnych można w polskim systemie wyodrębnić między innymi opiekę ambulatoryjną, opiekę szpitalną i opiekę długoterminową (tabela 6). 
Tabela 6. Infrastruktura i świadczenia systemu ochrony zdrowia w latach 1990-2016

\begin{tabular}{|c|c|c|c|c|c|c|c|}
\hline & 1990 & 1995 & 2000 & 2005 & 2010 & 2015 & 2016 \\
\hline Liczba szpitali ogólnych & 677 & 705 & 716 & 824 & 836 & 956 & 957 \\
\hline w tym szpitale niepubliczne & - & 9 & 30 & 170 & 286 & b.d. & b.d. \\
\hline Łóżka w szpitalach ogólnych w tys. & 219 & 214 & 191 & 187 & 190 & 187 & 187 \\
\hline Łóżka w szpitalach ogólnych na 10 tys. & 57,2 & 55,9 & 49,9 & 47,0 & 49,4 & 48,6 & 48,6 \\
\hline Leczeni w szpitalach ogólnych w tys. & 4597 & 5143 & 6007 & 7116 & 7759 & 7795 & 7829 \\
\hline $\begin{array}{l}\text { Leczeni w szpitalach ogólnych na } 10 \text { tys. } \\
\text { ludności }\end{array}$ & 1209 & 1344 & 1570 & 1766 & 2014 & 2027 & 2037 \\
\hline Liczba przychodni w tys. & 9,9 & 9,8 & 8,2 & 12,1 & 16,9 & 20,4 & 21,3 \\
\hline Praktyki lekarskie w tys. & b.d. & b.d. & 5,0 & 3,8 & 1,6 & 1,1 & 1,0 \\
\hline Praktyki stomatologiczne $w$ tys. & b.d. & b.d. & b.d. & 3,2 & 5,3 & 4,5 & 4,3 \\
\hline $\begin{array}{l}\text { Porady w zakresie opieki ambulatoryjnej } \\
\text { na } 1 \text { osobę* }\end{array}$ & 7,1 & 6,4 & 6,1 & 7,0 & 7,5 & 8,3 & 8,4 \\
\hline $\begin{array}{l}\text { Porady lekarskie w zakresie opieki } \\
\text { ambulatoryjnej na } 1 \text { osobę }\end{array}$ & 5,8 & 5,4 & 5,4 & 6,3 & 6,7 & 7,4 & 7,5 \\
\hline Liczba zakładów opiekuńczo-leczniczych & - & - & 126 & 251 & 330 & 408 & 400 \\
\hline $\begin{array}{l}\text { Leczeni w zakładach opiekuńczo- } \\
\text {-leczniczych }\end{array}$ & - & - & 16340 & 31846 & 39606 & 47624 & 47398 \\
\hline Zakłady pielęgnacyjno-opiekuńcze & - & - & 60 & 128 & 137 & 152 & 154 \\
\hline $\begin{array}{l}\text { Leczeni w zakładach pielęgnacyjno- } \\
\text {-opiekuńczych }\end{array}$ & - & - & 5839 & 13871 & 13613 & 14214 & 13655 \\
\hline
\end{tabular}

b.d. - dane GUS uwzględniają strukturę opieki zdrowotnej obowiązującą przed wejściem w życie ustawy o działalności leczniczej z 15 kwietnia 2011 r., Dz.U. nr 112, poz. 654.

* bez porad opłacanych wyłącznie ze środków prywatnych.

Źródło: „Rocznik Statystyczny Rzeczypospolitej Polskiej” GUS, za poszczególne lata.

Struktura właścicielska podmiotów opieki zdrowotnej w Polsce jest zróżnicowana. Większość szpitali ogólnych stanowi własność publiczną. Są to szpitale należące między innymi do jednostek samorządu terytorialnego, uczelni medycznych i resortów. W przypadku podmiotów podstawowej opieki zdrowotnej i ambulatoryjnej opieki specjalistycznej struktura jest bardziej zróżnicowana znaczna ich część to podmioty niepubliczne działające na podstawie umów na udzielanie świadczeń zdrowotnych finansowanych ze środków publicznych. Obywatele mają możliwość wyboru świadczeniodawcy. Obecna struktura właścicielska podmiotów opieki zdrowotnej zaczęła wyłaniać się na fali przemian społeczno-gospodarczych zainicjowanych w latach 90. XX wieku. Wcześniej podmioty opieki zdrowotnej należały do państwa. Istotną cechą tamtego systemu była tzw. rejonizacja - ograniczanie zasięgu działalności podmiotów opieki zdrowotnej do osób zamieszkałych w danym rejonie bądź zatrudnionych w konkretnym zakładzie pracy.

\section{Opieka ambulatoryjna}

Podstawowa opieka zdrowotna oraz ambulatoryjna opieka specjalistyczna stanowią główny szczebel systemu ochrony zdrowia. Od ich sprawności i skutecz- 
ności w istotnym stopniu zależy efektywność całego procesu leczenia pacjenta i wydolność systemu opieki zdrowotnej.

Szczególne znaczenie przypisuje się opiece podstawowej nie tylko w zakresie leczenia, ale również udzielania świadczeń z zakresu promocji zdrowia i profilaktyki oraz rehabilitacji. Kluczowa rola podstawowej opieki zdrowotnej w realizacji idei „Zdrowie dla wszystkich” ${ }^{37}$ podkreślana jest od dawna, czego wyrazem jest deklaracja z Ałma Aty, przyjęta na Światowym Zgromadzeniu Zdrowia w 1978 r. i odnowiona w 2018 r. w Astanie ${ }^{38}$.

Zgodnie z przedstawianymi corocznie przez GUS danymi w końcu 2016 r. w ambulatoryjnej opiece zdrowotnej funkcjonowało ogółem 21,3 tys. przychodni, 4,3 tys. praktyk stomatologicznych i 1 tys. praktyk lekarskich świadczących usługi w ramach środków publicznych. W porównaniu z 2005 r. zwiększyła się liczba przychodni (wzrost z 12,1 tys.) oraz praktyk stomatologicznych (wzrost z 3,2 tys.), natomiast zmniejszyła się liczba praktyk lekarskich (spadek z 3,8 tys.) (tabela 6).

Ogółem w 2016 r. w ambulatoryjnej opiece zdrowotnej udzielono ponad 323,1 mln porad. Wśród udzielonych porad - 52,5\% udzielono w podstawowej opiece zdrowotnej, 36,6\% - w opiece specjalistycznej i 10,9\% w opiece stomatologicznej. Porady udzielone w przychodniach stanowiły $95,9 \%$ wszystkich porad $^{39}$.

W 2016 r. liczba podmiotów ambulatoryjnych na 10 tys. mieszkańców w Polsce wynosiła 7,1. Struktura przestrzenna rozmieszczenia placówek ambulatoryjnych była jednak wyraźnie zróżnicowana. Liczba podmiotów ambulatoryjnych na 10 tys. mieszkańców była najniższa w województwie pomorskim $(5,4)$, a najwyższa w województwie warmińsko-mazurskim $(8,4)^{40}$.

Liczba porad w zakresie opieki ambulatoryjnej na osobę w 2016 r. wynosiła 8,4 . Był to kolejny rok, w którym liczba udzielonych porad wzrosła. Z kolei liczba porad lekarskich wynosiła 7,5. Największą liczbę porad lekarskich na jednego mieszkańca udzielono w województwie łódzkim i śląskim (po 8,0), a najmniejszą w województwie opolskim $(6,7)$. W przypadku porad stomatologicznych na jednego mieszkańca najwięcej odnotowano ich w województwie lubelskim $(1,2)$, a najmniej w województwach wielkopolskim, lubuskim i opolskim $(\text { po } 0,7)^{41}$.

37 H. Mahler, The Meaning of „Health for All by the Year 2000”, „American Journal of Public Health” 2016 nr 106(1), s. 36-38, https://doi.org/10.2105/AJPH.2016.106136.

38 Declaration of Astana, Global Conference on Primary Health Care From Alma-Ata towards universal health coverage and the Sustainable Development Goals Astana, Kazakhstan, 25 and 26 October 2018, https://www.who.int/docs/default-source/primary-health/ declaration/gcphc-declaration.pdf [dostęp: 7 grudnia 2018 r.].

39 GUS, Zdrowie i ochrona zdrowia w 2016 r., Warszawa 2017.

40 Ibidem.

${ }^{41}$ Ibidem. 


\section{Opieka szpitalna}

Opieka szpitalna jest najbardziej kosztowną formą opieki zdrowotnej. Dla redukcji zapotrzebowania na opiekę szpitalną najważniejsza jest podstawowa i ambulatoryjna opieka zdrowotna, a także działania z zakresu zdrowia publicznego. Za koniecznością poszukiwania nowych rozwiązań przemawia zmieniający się charakter problemów zdrowotnych, w tym zwłaszcza zwiększające się obciążenie chorobami przewlekłymi.

Zgodnie $\mathrm{z}$ danymi GUS ${ }^{42}$ na temat systemu ochrony zdrowia w Polsce w 2016 r. funkcjonowało 957 stacjonarnych szpitali ogólnych ${ }^{43}$, dysponujących 186,6 tys. łóżek. Zapotrzebowanie na świadczenia szpitalne w Polsce wzrasta. Liczba hospitalizacji w szpitalach ogólnych, wynosząca w 2000 r. 6 mln, w 2016 r. wynosiła już 7,8 mln, tj. zwięlkszyła się o 30\%, tym samym wzrosła wartość wskaźnika liczby leczonych w szpitalach na 10 tys. ludności, z 1570 do 2037 (tabela 6).

Możliwość porównywania danych o liczbie szpitali ze względu na zmiany prawne jest ograniczona. Niemniej można stwierdzić, że od lat 90. ubiegłego wieku liczba szpitali ogólnych zwiększała się. Wzrost ten odbywał się głównie poprzez zwiększanie liczby szpitali niepublicznych.

W 2016 r. liczba szpitali ogólnych w odniesieniu do liczby ludności wyniosła 2,5 szpitala na 100 tys. mieszkańców. Występowały jednak wyraźne różnice między regionami. Wskaźnik ten osiągał największą wartość w województwie śląskim $(3,4)$, a najniższą w województwie wielkopolskim $(1,7)$. Wskaźnik łóżek w szpitalach ogólnych na 10 tys. mieszkańców wynosił 48,6. Podobnie jak w przypadku wskaźnika liczby szpitali wskaźnik ten był wyraźnie zróżnicowany między regionami. Największą wartość osiągnął w województwie śląskim $(55,8)$, a najniższą w województwie pomorskim $(39,4)^{44}$.

W porównaniu z innymi państwami Unii Europejskiej Polska ma jeden z najwyższych wskaźników liczby łóżek szpitalnych przypadających na 100 tys. mieszkańców. Zarazem liczba szpitali w stosunku do liczby ludności jest stosunkowo niska, co wskazuje na znaczny udział wśród polskich szpitali dużych jednostek dysponujących dużą liczbą łóżek. Według danych Eurostatu liczba łóżek w Polsce na 100 tys. mieszkańców w 2016 r. wynosiła 664, przy przeciętnej dla państw UE wynoszącej 503,5. Co istotne, liczba łóżek w Polsce od 2005 r., kiedy wynosiła 652,1 na 100 tys. mieszkańców, utrzymuje się na stabilnym poziomie, podczas gdy w wielu innych państwach uległa wyraźnemu zmniejszeniu (przeciętnie w UE nastąpił spadek o 13,5\%). Przykładem najbardziej spektakularnych

${ }^{42}$ Ibidem.

43 Według danych GUS (Bank Danych Lokalnych) w porównaniu z 2004 r. liczba szpitali wzrosła o 167 , tj. o $21,1 \%$.

44 GUS, Zdrowie i ochrona zdrowia w 2016 r., op. cit. 
zmian mogą być takie państwa, jak Irlandia, Finlandia, Dania i Wielka Brytania, w których między 2004 r. i 2016 r. wskaźnik ten obniżył się odpowiednio: z 545,9 do 259,9 (czyli spadek o 52,4\%); z 705,2 do 397,3 (43,7\%); z 385,6 do 259,6 (34,6\%); z 373,4 do 257,5 (31,0\%). Nie bez znaczenia jest również struktura łóżek szpitalnych - w Polsce struktura ta od 2005 r. pozostaje stabilna, z istotną nadwyżką łóżek opieki doraźnej ${ }^{45}$.

Porównywanie liczby łóżek szpitalnych między państwami ma swoje ograniczenia, wynikające z organizacji systemu ochrony zdrowia i specyfiki konkretnych państw. W związku z tym nie można wyciągać pochopnych wniosków co do konieczności redukcji liczby łóżek szpitalnych w Polsce bez szczegółowej analizy zapotrzebowania w poszczególnych dziedzinach medycyny.

Istniejące w Polsce zróżnicowania regionalne pod względem liczby szpitali i łóżek szpitalnych powodują różnice w dostępie do leczenia szpitalnego. $\mathrm{Na}$ obecną strukturę przestrzenną wpływ ma wiele czynników, w tym między innymi czynniki społeczno-polityczne i historyczne. Dodatkowa trudność w uporządkowaniu istniejącej struktury wynika z pojawienia się małych szpitali prywatnych, specjalizujących się w wykonywaniu na podstawie kontraktów z NFZ najbardziej atrakcyjnych finansowo procedur, w tym między innymi kardiologii naczyniowej i interwencyjnej.

Występujące różnice $\mathrm{w}$ dostępie do infrastruktury między jednostkami samorządu terytorialnego nie wynikają bezpośrednio z odmiennych potrzeb zdrowotnych populacji. Jak wskazują dotychczasowe kontrole NIK, świadczeniodawcy nierzadko inwestowali, np. w zakupy nowoczesnego sprzętu, prace budowlane, zwiększenie zatrudnienia personelu medycznego, bez rozpoznania potrzeb zdrowotnych. Takie decyzje były podejmowane, mimo że $\mathrm{w}$ danym regionie działały już inne podmioty lecznicze udzielające tych samych świadczeń. Efektem tego był różny stopień wykorzystania dostępnych zasobów. Analiza umów świadczeniodawców z NFZ przeprowadzona przez NIK wykazała, że w latach 2010-2016 wielu świadczeniodawców wykazywało wykonanie świadczeń ponad limit, podczas gdy inni nie realizowali w pełni kontraktów. Taka sytuacja świadczy o strukturalnym niedopasowaniu podaży świadczeń do potrzeb zdrowotnych ludności. Jak wskazał NIK, w części województw nie zapewniono dostępu do świadczeń zdrowotnych, w tym na poziomie ambulatoryjnej opieki specjalistycznej i lecznictwa szpitalnego, a dostęp do już zakontraktowanych świadczeń był zróżnicowany. W efekcie tego występowała migracja pacjentów do województw z najlepiej rozwiniętą bazą materialną i kadrową ${ }^{46}$.

${ }^{45} \mathrm{Http}: / /$ appsso.eurostat.ec.europa.eu/nui/submitViewTableAction.do [dostęp: 7 grudnia $2018 \mathrm{r}$.].

${ }^{46}$ NIK, „Tworzenie map potrzeb zdrowotnych”, informacja o wynikach kontroli, nr ewid. 191/2017/P/17/059/KZD, 2018, https:/www.nik.gov.pl/plik/id,16703,vp,19258.pdf. 


\section{Opieka długoterminowa}

Ze względu na postępujący proces starzenia się populacji, przemiany stylu życia, rodziny i rynku pracy coraz większą rolę w polskim systemie ochrony zdrowia zaczyna odgrywać instytucjonalna opieka długoterminowa. Opieka nad osobami potrzebującymi pomocy świadczona tradycyjnie najczęściej nieformalnie przez kobiety musi być coraz częściej świadczona przez wyspecjalizowane instytucje. Opieka instytucjonalna jest jednak w Polsce słabo rozwinięta. Liczba zakładów opiekuńczo-leczniczych oraz zakładów pielęgnacyjno-opiekuńczych między 2000 i 2016 r. wyraźnie wzrosła (odpowiednio o 217,5\% i 156,6\%). W tym czasie wzrosła też liczba osób leczonych w tych zakładach - o 190,1\% oraz $133,8 \%$ (tabela 6). Wiadomo jednak powszechnie, że popyt na formalne świadczenia opieki długoterminowej rośnie nieproporcjonalnie do podaży tych świadczeń, a problem potęguje niedobór personelu pielęgniarskiego ${ }^{47}$.

Wskaźnik liczby łóżek opieki długoterminowej w Polsce, wynoszący w 2015 r. 12,3 na 1000 osób w wieku co najmniej 65 lat, należał do najniższych wśród państw OECD. Był znacznie niższy niż średnia wynosząca 49,7 w państwach naszego regionu, jak np. Słowacja $(58,3)$, Węgry $(57,5)$, Niemcy $(54,5)$, Czechy $(48)^{48}$.

\section{Koordynacja opieki zdrowotnej}

Przedstawione dane nie pokazują istotnego problemu w polskim systemie opieki zdrowotnej, jakim jest zarządzanie systemem, a dokładnie niedostatek koordynacji między jednostkami podstawowej opieki zdrowotnej i ambulatoryjnej opieki specjalistycznej oraz szpitalami. Doświadczenia innych państw wskazują, że koordynacja opieki ma zasadnicze znaczenie dla poprawy jakości i efektywności opieki zdrowotnej.

Koordynowana opieka zdrowotna może być zdefiniowana jako zestaw działań mających na celu osiągnięcie wysokiego poziomu ochrony zdrowia przy ograniczeniu zbędnych kosztów opieki zdrowotnej dzięki stosowaniu mechanizmów, takich jak:

- zachęty ekonomiczne dla lekarzy i pacjentów motywujące do wyboru optymalnych form opieki,

- ocena medycznej konieczności dostarczania wybranych usług,

- wyważenie podziału kosztów ponoszonych przez beneficjenta,

- kontrole przyjęć szpitalnych i długości pobytu, ustanowienie zachęt do prowadzenia zabiegów w trybie ambulatoryjnym, selektywne kontraktowanie dostawców usług opieki zdrowotnej, intensywne zarządzanie w wypadkach wysokich kosztów opieki zdrowotnej.

47 Health at a Glance 2017: OECD Indicators, op. cit.

48 Health at a Glance: Europe 2018, op. cit. 
Przez koordynowaną opiekę zdrowotną określa się sieć współpracujących ze sobą dostawców usług medycznych, tworzoną przez menedżerów przejmujących odpowiedzialność finansową i organizacyjną za zapewnienie dostępu do stosunkowo szerokiego zakresu usług medycznych, koordynujących opiekę nad swoimi pacjentami, zapewniających ciągłość leczenia i wewnętrzny nadzór nad jego jakością. Wskazywane przez ekspertów korzyści z wprowadzania koordynowanej opieki zdrowotnej to między innymi poprawa dostępności czasowej i przestrzennej, lepsze dostosowanie profilu świadczeń do realnych potrzeb zdrowotnych, zwiększona aktywność prewencyjna, poprawa przepływu informacji między segmentami opieki zdrowotnej, odpowiedzialność świadczeniodawców za finansowe skutki decyzji terapeutycznych i bardziej efektywne wykorzystanie istniejących zasobów. Potencjalne słabości to między innymi dwupoziomowość systemu opieki medycznej w przypadku nieobjęcia opieką całej populacji, skłonność do ograniczania świadczeń zasadnych z medycznego punktu widzenia przy braku instrumentów nadzoru nad jakością, przerzucanie kosztów na wyższe poziomy przy wąskich zakresach odpowiedzialności finansowej ${ }^{49}$.

Momentem przełomowym w zakresie wprowadzania do polskiego systemu zdrowia koordynacji opieki miało być przyjęcie w 2017 r. regulacji ustawowych tworzących tzw. sieć szpitali ${ }^{50}$. Ustawa ta wprowadziła rozwiązania, które w założeniu miały usprawnić organizację udzielania świadczeń opieki zdrowotnej przez szpitale oraz przychodnie przyszpitalne i poprawić dostęp pacjentów do leczenia specjalistycznego w szpitalach. Zaproponowane rozwiązania miały doprowadzić do optymalizacji liczby oddziałów specjalistycznych i umożliwić lepszą koordynację świadczeń szpitalnych i ambulatoryjnych, a także ułatwić zarządzanie szpitalami. W założeniu ustawodawcy szpitale spełniające określone kryteria kwalifikacyjne miały utworzyć tzw. system podstawowego szpitalnego zabezpieczenia świadczeń opieki zdrowotnej. Tylko szpitalom należącym do sieci zagwarantowano publiczne finansowanie w ramach ryczałtu. Nowe regulacje miały służyć utrzymaniu odpowiedniego poziomu, a także ciągłości i stabilności finansowania szpitali, których funkcjonowanie jest niezbędne dla zapewnienia Polakom opieki zdrowotnej.

Od wprowadzenia koncepcji sieci szpitali upłynęło stosunkowo niewiele czasu. Należy podkreślić, że choć regulacja dotyczyła zasadniczej części sek-

49 K. Kowalska, W.P. Kalbarczyk, Koordynowana opieka zdrowotna. Doświadczenia międzynarodowe, propozycje dla Polski, Warszawa 2013, raport przygotowany w ramach programu EY „Sprawne Państwo”, https://www.ey.com/Publication/vwLUAssets/EY_ Sprawne_Pa\%C5\%84stwo_Raport_Koordynowana_Opieka_Zdrowotna/\$FILE/EY_Sprawne_Panstwo_KOZ.pdf [dostęp: 1 września 2018 r.].

50 Wprowadzenie sieci szpitali nastąpiło poprzez nowelizację ustawy z 27 sierpnia $2004 \mathrm{r}$. o świadczeniach opieki zdrowotnej finansowanych ze środków publicznych, Dz.U. 2018, poz. 1510. Zob. także http://siecszpitali.mz.gov.pl/ [dostęp: 1 września 2018 r.]. 
tora opieki zdrowotnej, to nie została przeprowadzona szczegółowa analiza potencjalnych skutków tej regulacji. Co więcej, nie przewidziano istotnego zwiększenia finansowania. Realna ocena funkcjonowania sieci szpitali wymaga jeszcze czasu. Wstępne oceny funkcjonowania sieci szpitali są niejednoznaczne. Strona społeczna, tj. dyrektorzy i właściciele szpitali wskazują na rosnące problemy wynikające między innymi z niedostatków finansowania. Z drugiej strony przedstawiciele Ministerstwa Zdrowia przekonują, że sieć szpitali spełnia swoje zadania, służąc poprawie funkcjonowania placówek oraz zaspokajaniu potrzeb pacjentów. Mimo to resort zdrowia sygnalizuje konieczność wprowadzenia korekt.

\section{Dostęp do świadczeń}

W Polsce prawo obywateli do ochrony zdrowia jest zagwarantowane w Konstytucji RP. Zgodnie z obowiązującymi zasadami władze publiczne są zobowiązane do zapewnienia obywatelom równego dostępu do opieki zdrowotnej finansowanej ze środków publicznych, przy czym to władze publiczne wyznaczają zakres tej opieki, czyli określają, które produkty lecznicze i procedury medyczne są ujęte w koszyku świadczeń objętych publicznym systemem ubezpieczenia zdrowotnego. Koszyk świadczeń gwarantowanych w Polsce jest stosunkowo szeroki, co przy ograniczonych zasobach systemu ochrony zdrowia sprawia, że uzyskanie świadczeń zdrowotnych nierzadko wymaga długiego oczekiwania.

Przyczyny niekorzystania z porad lekarzy według badań GUS z 2016 r. były zróżnicowane ${ }^{51}$. Głównym powodem niekorzystania z porad lekarza podstawowej opieki zdrowotnej było oczekiwanie na ustąpienie objawów $(41,8 \%)$, brak czasu $(17,3 \%)$, długi czas oczekiwania na termin wizyty $(12,8 \%)$, brak pieniędzy $(6,7 \%)$, niedostosowany czas przyjęć $(6,5 \%)$, trudności z dojazdem $(5,0 \%)$ oraz strach $(3,0 \%)$. W przypadku niekorzystania z porad lekarzy specjalistów najważniejsze przyczyny to długi czas oczekiwania na termin wizyty (46,0\%), brak pieniędzy (13,1\%), oczekiwanie na ustąpienie objawów $(10,1 \%)$, brak czasu $(9,8 \%)$, trudności z dojazdem $(7,3 \%)$, niedostosowany czas przyjęć $(4,2 \%)$ i strach (3,3\%). Powody, jakie stoją za niewykonywaniem badań diagnostycznych, to między innymi: długi czas oczekiwania na termin badań $(23,2 \%)$, brak skierowania $(19,1 \%)$, strach $(14,2 \%)$ i brak pieniędzy $(14,0 \%)$. Powody niekorzystania ze świadczeń zdrowotnych wskazują na kłopoty w dostępności geograficznej, czasowej i ekonomicznej, a także potrzebę działań uświadamiających pacjentów, że występujące objawy nie mogą być bagatelizowane.

Jak wskazują analizy prowadzone przez fundację Watch Health Care (WHC), przeciętny czas oczekiwania na pojedyncze gwarantowane świadczenia zdrowotne (niezależnie od ich charakteru: diagnostyczne i lecznicze bez uwzględnienia w tej ocenie kompleksowości i niezbędnej etapowości leczenia) w Polsce

${ }^{51}$ GUS, Ochrona zdrowia w gospodarstwach domowych w 2016 r., op. cit. 
w kwietniu i maju 2018 r. wynosił ok. 3,7 miesiąca ${ }^{52}$. Co istotne, przeciętny czas oczekiwania stale się wydłuża. W 2018 r. najdłużej trzeba było czekać na świadczenia u lekarzy następujących specjalności: endokrynolog (23 miesiące), ortodonta $(11,7)$, immunolog $(9)$, angiolog $(7,8)$, kardiolog dziecięcy $(7,3)$, hepatolog $(7,1)$, kardiolog $(5,7)$.

Na tle innych państw sytuacja w Polsce może być oceniana jako niezadowalająca. Na przykład na takie zabiegi medyczne jak operacja zaćmy i wstawienie endoprotezy trzeba czekać najdłużej w całej UE ${ }^{53}$.

Dostęp do usług zdrowotnych jest zróżnicowany. Badania pokazują, że na występowanie w Polsce dużych nierówności w dostępie do usług medycznych wpływ ma pozycja społeczna i ekonomiczna. Okazało się, że w 2015 r. największe problemy dotyczyły tych grup, które potencjalnie najbardziej usług zdrowotnych potrzebowały, czyli rodzin wielodzietnych, rodzin niepełnych, rencistów i emerytów. Problemy w największym stopniu dotyczyły dostępu do sanatorium, rehabilitacji, leczenia zębów i zakupu leków. Warto zwrócić uwagę na bardzo duże różnice w zależności od sytuacji materialnej. Badania wskazują, że blisko $1 / 8$ obywateli nie była w stanie sfinansować potrzebnego leczenia zębów, zakupu protez czy też wyjazdu do sanatorium (tabela 7).

$\mathrm{Na}$ tle innych państw Polska była krajem o jednym z najwyższych udziałów osób deklarujących niezaspokojoną potrzebę konsultacji lekarskiej. W zależności od dochodów deklarowało tak: $8,8 \%$ populacji o wysokich dochodach, $6,3 \%$ o średnich dochodach oraz 10,8\% o niskich dochodach, przy średnich wartościach tego wskaźnika dla krajów OECD w 2013 r., wynoszących odpowiednio: 3\%, 1,3\% i 5,1\%. W zakresie dostępu do świadczeń stomatologicznych sytuacja była zauważalnie lepsza (Polska: 5,1\%, 2,8\%, 7,9\% oraz OECD: 5\%, 1,6\%, 9,6\%).

Problemy z dostępem do usług zdrowotnych znajdują odzwierciedlenie w badaniach opinii publicznej. Zgodnie z badaniami CBOS z 2018 r. 66\% ankietowanych negatywnie ocenia funkcjonowanie ochrony zdrowia w Polsce, w tym $27 \%$ zdecydowanie negatywnie ${ }^{54}$. Wyniki badań doświadczeń samych pacjentów z opieką zdrowotną wskazują, że sytuacja w Polsce wyraźnie odbiega od sytuacji w innych państwach. Na pytanie czy lekarz poświęca pacjentowi wystarczająco dużo czasu w trakcie konsultacji uzyskano 59,6\% odpowiedzi twierdzących przy średniej w UE 82,8\%. Na pytanie, czy lekarz rozmawia z pacjentem w zrozumiały

${ }^{52}$ Raport na temat zmian $w$ dostępności do gwarantowanych świadczeń zdrowotnych w Polsce $n r$ 18/27/06/2018, stan na kwiecień/maj 2018 r., http://wei.org.pl/wp-content/ uploads/2018/06/Raport-na-temat-zmian-w-dostępności-do-gwarantowanych-świadczeń-zdrowotnych-w-Polsce.pdf [dostęp: 1 września 2018 r.].

${ }_{53}$ OECD/European Observatory on Health Systems and Policies, Polska: Profil systemu ochrony zdrowia 2017, op. cit.

${ }_{44}$ Opinie na temat funkcjonowania opieki zdrowotnej, komunikat z badań CBOS, nr 89/2018, https://www.cbos.pl/SPISKOM.POL/2018/K_089_18.PDF [dostęp: 20 listopada 2018 r.]. 
Tabela 7. Odsetek gospodarstw domowych w 2015 r., które zrezygnowały z powodów finansowych z wybranych świadczeń zdrowotnych, mimo że ich potrzebowały

\begin{tabular}{|c|c|c|c|c|c|c|c|c|}
\hline & 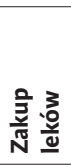 & 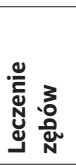 & 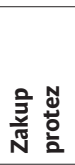 & 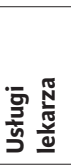 & $\begin{array}{l}\frac{\pi}{5} \\
\frac{\pi}{0} \\
\text { D } \\
0\end{array}$ & 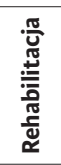 & 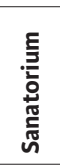 & $\frac{\bar{\pi}}{\frac{\pi}{2}}$ \\
\hline Ogółem & 14,3 & 18,9 & 20,5 & 13,7 & 9,7 & 20,1 & 24,9 & 2,2 \\
\hline Górny kwartyl dochodów & 2,4 & 4,5 & 4,6 & 2,9 & 2,5 & 6,7 & 6,1 & 0,6 \\
\hline Dolny kwartyl dochodów & 34,6 & 45,2 & 46,3 & 31,0 & 24,2 & 39,4 & 48,6 & 5,0 \\
\hline Małżeństwa z 3 dzieci i więcej & 17,7 & 23,5 & 18,8 & 17,0 & 11,5 & 25,0 & 27,4 & 2,3 \\
\hline Rodziny niepełne & 23,9 & 30,5 & 30,2 & 20,0 & 18,1 & 34,3 & 38,3 & 2,4 \\
\hline Renciści & 33,3 & 40,4 & 39,9 & 30,1 & 20,7 & 37,0 & 49,5 & 2,8 \\
\hline Emeryci & 16,8 & 16,3 & 17,5 & 15,6 & 10,2 & 19,1 & 23,6 & 2,0 \\
\hline
\end{tabular}

Źródło: Diagnoza społeczna 2015. Warunki i jakość życia Polaków. Raport, red. J. Czapiński, T. Panek, Rada Monitoringu Społecznego, Warszawa 2015, s. 120.

dla pacjenta sposób, pozytywnych odpowiedzi udzieliło 69,5\% osób w Polsce, przy średniej w UE 86,5\%. Pytanie o to, czy lekarz umożliwia pacjentowi branie udziału w podejmowaniu decyzji odnośnie do opieki i leczenia, uzyskało 47,9\% pozytywnych odpowiedzi (średnia UE 78,3\%), a pytanie, czy lekarz umożliwia pacjentowi zadawanie pytań i wyrażanie obaw - 33,6\%, przy średniej w UE 83,2\% ${ }^{55}$.

Funkcjonowanie systemu ochrony zdrowia w Polsce jest stałym przedmiotem skarg kierowanych do Rzecznika Praw Obywatelskich (RPO). Na podstawie zgłaszanych skarg RPO przygotowuje wystąpienia z rekomendacjami i analizami konkretnych problemów. Niezmiennie najpoważniejszym problemem pozostaje dostępność i jakość udzielanych świadczeń. W wystąpieniu z 2017 r. RPO sformułował wiele zaleceń, w tym między innymi:

- potrzebę zapewnienia równego dostępu do poszczególnych świadczeń we wszystkich regionach kraju,

- wprowadzenie regulacji dotyczących standardu żywienia w szpitalach,

- doprowadzenie do konstytucyjnego standardu opieki zdrowotnej nad szczególnie chronionymi kategoriami pacjentów,

- zwiększenie uwagi władz publicznych co do ochrony zdrowia psychicznego,

- podjęcie zdecydowanych kroków na rzecz przeciwdziałania dyskryminacji niektórych grup pacjentów,

- zakończenie praktyki faktycznego ograniczania dostępu do świadczeń finansowanych ze środków publicznych ${ }^{56}$.

55 Health at a Glance 2017: OECD Indicators, op. cit.

56 Rzecznik Praw Obywatelskich do Ministra Zdrowia z wykazem problemów w służbie zdrowia, 10 listopada 2017 r., numer pisma: V.7010.82.2017.ŁK. 


\section{System informacji zdrowotnej}

Zgodnie z ujęciem zaproponowanym przez WHO system informacji zdrowotnej powinien zapewniać pozyskiwanie, analizę, rozpowszechnianie oraz korzystanie $z$ wiarygodnych i aktualnych informacji na temat stanu zdrowia ludności, uwarunkowań zdrowotnych oraz funkcjonowania systemów zdrowotnych.

Podkreśla się, że informacja jest warunkiem planowania działań z zakresu zdrowia i pozwala na monitorowanie działań już podjętych. Z kolei zarządzanie informacją poprawia efektywność i przyczynia się do obniżenia kosztów.

Kwestie organizacji i zasad systemu informacji w polskim systemie ochrony zdrowia są regulowane ustawowo ${ }^{57}$. System informacji obejmuje bazy danych tworzone przez podmioty obowiązane do ich prowadzenia, zawierające dane o: udzielonych, udzielanych i planowanych świadczeniach opieki zdrowotnej; usługodawcach i pracownikach medycznych; usługobiorcach.

System informacji obejmuje bazy danych funkcjonujące w Systemie Informacji Medycznej oraz w ramach dziedzinowych systemów teleinformatycznych, tj. Systemu Rejestru Usług Medycznych Narodowego Funduszu Zdrowia, Systemu Statystyki w Ochronie Zdrowia, Systemu Ewidencji Zasobów Ochrony Zdrowia, Systemu Monitorowania Zagrożeń, Systemu Monitorowania Dostępności do Świadczeń Opieki Zdrowotnej, Systemu Monitorowania Kosztów Leczenia, Zintegrowanego Systemu Monitorowania Obrotu Produktami Leczniczymi, Systemu Monitorowania Kształcenia Pracowników Medycznych, Systemu Obsługi List Refundacyjnych, Instrumentu Oceny Wniosków Inwestycyjnych w Sektorze Zdrowia.

Jednostką odpowiedzialną za systemy informacyjne jest podległe Ministrowi Zdrowia Centrum Systemów Informacyjnych Ochrony Zdrowia. Centrum odpowiedzialne było za realizowanie wielu projektów, takich jak: „Elektroniczna platforma gromadzenia, analizy i udostępniania zasobów cyfrowych o zdarzeniach medycznych” (projekt P1), „Platforma udostępniania on-line przedsiębiorcom usług i zasobów cyfrowych rejestrów medycznych” (P2), „Poprawa jakości zarządzania w ochronie zdrowia poprzez popularyzację wiedzy na temat technologii ICT” (P3) oraz „Dziedzinowe systemy teleinformatyczne systemu informacji w ochronie zdrowia” $(\mathrm{P} 4)^{58}$. Projekty te realizowane w ostatnich latach wymagały nie tyle stworzenia systemu, co reorganizacji i połączenia wielu systemów baz danych funkcjonujących do tej pory niezależnie. W zakresie wprowadzania tych rozwiązań należy wskazać konieczność uwzględniania licznych ograniczeń, związanych między innymi z umiejętnościami korzystania

57 Ustawa z 28 kwietnia 2011 r. o systemie informacji w ochronie zdrowia, Dz.U. 2017, poz. 1845 , ze zm.

58 Strona internetowa Centrum Systemów Informacyjnych Ochrony Zdrowia, https:// www.csioz.gov.pl/ [dostęp: 1 września 2018 r.]. 
z nowoczesnych technologii przez pracowników medycznych - zwłaszcza tych w starszych grupach wiekowych, dostępem do odpowiedniego sprzętu komputerowego i szerokopasmowym dostępem do internetu. Osiągnięte do tej pory rezultaty wprowadzania programów trudno ocenić jednoznacznie pozytywnie. Niemniej podjęcie tych działań było konieczne.

Jednym ze sztandarowych projektów w zakresie systemu informacji zdrowotnych w Polsce było opracowanie map potrzeb zdrowotnych. Zgodnie z przyjętymi regulacjami mapy potrzeb zdrowotnych miały zostać przygotowane na podstawie danych epidemiologicznych, demograficznych i danych $\mathrm{z}$ rejestru podmiotów wykonujących działalność leczniczą. Mapy te miały być tworzone na poziomie regionalnym, tak aby uwzględniać specyfikę potrzeb zdrowotnych społeczności lokalnych. Na podstawie map stworzonych w regionach powstawała mapa ogólnopolska ${ }^{59}$. Mapy potrzeb zdrowotnych w założeniu miały służyć monitorowaniu systemu ochrony zdrowia oraz pozwalać na jego modyfikacje. Istotne jest to, że stworzenie map potrzeb zdrowotnych nie wynikało $\mathrm{z}$ inicjatywy Ministerstwa Zdrowia, ale było warunkiem, jaki Komisja Europejska postawiła Polsce, aby można było wykorzystać środki finansowe na inwestycje związane $\mathrm{z}$ ochroną zdrowia. Mapy potrzeb zdrowotnych opublikowane w 2016 r. zostały poddane ocenie przez Najwyższą Izbę Kontroli. W efekcie przeprowadzonej kontroli NIK stwierdził, że mapy zawierają liczne nierzetelne, a często także nieaktualne dane. Według NIK: formalne spetnienie warunków wymaganych przez UE, polegajace na opracowaniu map potrzeb zdrowotnych oraz dokonywanie na ich podstawie inwestycji wspótfinansowanych ze środków UE nie daje gwarancji przebudowy systemu ochrony zdrowia. Bez poprawy aktualności $i$ wiarygodności danych $w$ rejestrach i systemach teleinformatycznych, mapy będa w ograniczonym zakresie odzwierciedlaty rzeczywiste potrzeby ludności i slużyly kreowaniu polityki zdrowotnej państwa $a^{60}$. Zasadność zarzutu o nieaktualności danych można podawać $w$ wątpliwość. Zarzutem znacznie poważniejszym jest rzetelność danych. Należy stwierdzić, że wiarygodność danych, które zostały użyte do przygotowania map potrzeb zdrowotnych, jest niska. Nie może być to jednak zarzut pod adresem autorów map. Kwestia niskiej jakości danych, wynikająca z problemów gromadzenia i przetwarzania danych, jest problemem systemowym. Taka sytuacja stanowi poważne ograniczenie dla możliwości prowadzenia rzetelnych analiz.

Przykładem trudności w gromadzeniu i przetwarzaniu danych w Polsce jest rejestrowanie zgonów. Polska jest państwem, w którym rejestrowane są zasadniczo wszystkie zgony, jednak w przypadku znacznego odsetka zgonów lekarze orzekający zgon nieprawidłowo opisują jego przyczyny - według danych

${ }^{59}$ Art. 95a ustawy z 27 sierpnia 2004 r. o świadczeniach opieki zdrowotnej finansowanych ze środków publicznych, t.j. Dz.U. 2018, poz. 1510, ze zm.

${ }^{60}$ NIK, „Tworzenie map potrzeb zdrowotnych”, op. cit. 
z 2013 r. było to 29,5\% wszystkich zgonów. Główne zastrzeżenie dotyczy pomijania chronologicznego opisu łańcucha przyczyn/chorób odpowiedzialnych za zgon chorego lub nieprawidłowe jego przedstawienie, a w konsekwencji niewłaściwe lub nieprecyzyjne wskazanie wyjściowej przyczyny zgonu ${ }^{61}$. Problem niewłaściwego kodowania przyczyn zgonów jest problemem bardzo poważnym, ponieważ dysponowanie rzetelną informacją o zgonach i umieralności według przyczyn jest niezbędne dla prawidłowego określenia celów polityki zdrowotnej państwa oraz oceny jej skuteczności ${ }^{62}$.

W kontekście systemów informacji zdrowotnej warto wskazać na rosnące znaczenie nowoczesnych technologii informacyjnych. Według niektórych ekspertów nowoczesne technologie zrewolucjonizują system ochrony zdrowia ${ }^{63}$. Nowoczesne technologie mają pozwolić rozdzielić udzielanie świadczeń zdrowotnych, głównie z obszaru diagnostyki, od podmiotów opieki zdrowotnej. Podkreśla się znaczenie wspomagania procesu leczenia szczególnie pacjentów zmagających się z chorobami przewlekłymi. Duże nadzieje pokładane są w rozwoju sztucznej inteligencji, która mogłaby w wielu zadaniach wyręczać personel medyczny, np. radiologów. Warto wskazać również na pozytywne efekty kontaktowania w ramach sieci pacjentów, zwłaszcza pacjentów z chorobami rzadkimi.

W obliczu rosnących zastosowań systemów informacyjnych ważną kwestią staje się zapewnienie bezpieczeństwa danych przed dostępem osób niepowołanych. Wyzwanie to nie jest jednak wyłącznie wyzwaniem technicznym. Jest to również wyzwanie prawne, którego rozwiązanie wymaga nie tylko odpowiednich regulacji, ale też przygotowania obywateli do stosowania tych przepisów. Przykładem negatywnym, jaki można przywołać, jest wprowadzanie przepisów $\mathrm{RODO}^{64}$, które ze względu na wątpliwości interpretacyjne doprowadziło do licznych problemów dla pacjentów i personelu medycznego.

\section{Dostęp do produktów i technologii medycznych}

Zgodnie z podejściem wypracowanym przez WHO dla funkcjonowania systemu ochrony zdrowia niezbędne jest zapewnienie równego dostępu do produktów medycznych, szczepionek i technologii medycznych. Produkty i technologie powinny być: gwarantowanej jakości, bezpieczne, skuteczne i efektywne, naukowo uzasadnione oraz wykorzystywane efektywnie pod względem kosztów.

61 GUS, Statystyka umieralności w wyniku chorób układu krążenia, Warszawa 2016.

${ }^{6} \mathrm{Https} / / /$ stat.gov.pl/obszary-tematyczne/ludnosc/ludnosc/statystyka-zgonow-i-umieralnosci-z-powodu-chorob-ukladu-krazenia,22,1.html.

63 A revolution in health care is coming, „The Economist” $\mathrm{z} 1$ lutego $2018 \mathrm{r}$.

64 Rozporządzenie Parlamentu Europejskiego i Rady (UE) 2016/679 z 27 kwietnia 2016 r. w sprawie ochrony osób fizycznych w związku z przetwarzaniem danych osobowych i w sprawie swobodnego przepływu takich danych oraz uchylenia dyrektywy 95/46/WE (ogólne rozporządzenie o ochronie danych). 
W Polsce czuwa nad tym odrębna instytucja, którą jest Agencja Oceny Technologii Medycznych i Taryfikacji ${ }^{65}$.

Według szacunków fundacji Watch Health Care w 2015 r. niemal 1000 technologii nielekowych i ok. 250 innowacyjnych technologii lekowych zarejestrowanych w UE nie było w Polsce finansowane ze środków publicznych, choć często były to najskuteczniejsze technologie medyczne w różnych chorobach ${ }^{66}$.

Zapewnienie dostępu do produktów i technologii medycznych wcale nie oznacza, że będą one wykorzystywane. Przykładem mogą być szczepienia przeciw grypie, które mają wysoką skuteczność, a zarazem kosztują stosunkowo niewiele. W Polsce w 2015 r. w grupie osób powyżej 65. roku życia odsetek zaszczepionych wynosił 9,7, przy średniej OECD wynoszącej 43,2 i znacznie wyższych odsetkach w takich państwach jak Wielka Brytania $(71,1)$, Holandia $(66,8)$, Francja $(50,8)^{67}$.

W Polsce dostęp do leków jest ograniczony sytuacją finansową i potwierdzał istnienie nierówności zdrowotnych. Według wyników badania „Diagnoza Społeczna” w 2015 r. odsetek gospodarstw domowych, które zrezygnowały z powodów finansowych z zakupu leków, wynosił ogółem 14,3\%. W najtrudniejszej sytuacji były osoby utrzymujące się z niezarobkowych źródeł (zrezygnowało z zakupu 40,7\%), renciści $(33,3 \%)$ oraz emeryci $(16,8 \%)$. Problem ten dotyczył najczęściej małżeństw $\mathrm{z}$ trojgiem i więcej dzieci $(17,7 \%)$ oraz rodzin niepełnych $(23,9 \%)$, (tabela 7$)^{68}$.

Polska należy do państw o relatywnie wysokiej konsumpcji leków dostępnych bez recepty (OTC, ang. over the counter). Badania pokazują, że na ich promocję przypada najwięcej środków wydawanych na reklamę. Duża jest również konsumpcja suplementów diety. Rynek ten dynamicznie rośnie. Jak wskazują badania CBOS, w 2015 r. leki dostępne bez recepty i suplementy diety stosowało $89 \%$ dorosłych. Najczęściej były to środki przeciwbólowe i przeciwzapalne (68\%) oraz łagodzące objawy przeziębienia lub grypy (68\%), a także witaminy, minerały i środki poprawiające ogólną odporność organizmu (52\%). Co więcej, $28 \%$ deklarowało, że stosowało leki dostępne bez recepty w niewłaściwy sposób - niezgodnie za zaleceniami (20\%), lekceważąc skutki uboczne (9\%) lub przeciwwskazania, które ich dotyczą (8\%), z przyzwyczajenia, choć nie było to konieczne $(7 \%)$, oraz wbrew negatywnej opinii lekarza $(4 \%)^{69}$. Problemem jest

65 Art. 31n ustawy z 27 sierpnia 2004 r. o świadczeniach opieki zdrowotnej finansowanych ze środków publicznych.

${ }^{66}$ K. Łanda i in., Fundusz Walki z Rakiem (FWR) propozycje rozwiazań systemowych, Kraków 2015, http://www.korektorzdrowia.pl/wp-content/uploads/fundusz-walki-z-rakiem-fwr-propozycje-rozwiazan-systemowych.pdf [dostęp: 1 września 2018 r.].

67 Health at a Glance 2017: OECD Indicators, op. cit.

68 Diagnoza społeczna 2015. Warunki i jakość życia Polaków. Raport, red. J. Czapiński, T. Panek, Rada Monitoringu Społecznego, Warszawa 2015, s. 123.

69 Leki dostępne bez recepty i suplementy diety, komunikat $\mathrm{z}$ badań CBOS, nr 158/2016, Warszawa 2016, https://cbos.pl/SPISKOM.POL/2016/K_158_16.PDF [dostęp: 1 września 2018 r.]. 
również stosowanie w sposób niewłaściwy leków na receptę, w tym szczególnie niepokojące jest niewłaściwe stosowanie antybiotyków ${ }^{70}$.

Dostęp do produktów i technologii medycznych w Polsce jest ograniczony i nie jest równy dla wszystkich obywateli. Przyczyny tej sytuacji to nie tylko niedostateczny poziom finansowania, ale także obowiązujące regulacje i poziom edukacji zdrowotnej obywateli. Niski poziom edukacji zdrowotnej skutkuje między innymi wskazanymi wyżej problemami w zakresie korzystania z leków bez recepty, suplementów diety i ogólnie alternatywnych do proponowanych przez nauki medyczne metod i praktyk leczniczych, a także niedostatecznej wiedzy na temat skuteczności i bezpieczeństwa szczepień, które skutkuje podatnością na działania tzw. ruchów antyszczepionkowych. W celu poprawy sytuacji potrzebne są konsekwentne działania władz publicznych prowadzące do podnoszenia świadomości zdrowotnej społeczeństwa, związane z edukacją zdrowotną i polityką informacyjną oraz działaniami regulacyjnymi między innymi w zakresie promocji poszczególnych produktów i dostępu do nich.

\section{System finansowania}

Przyjmuje się za WHO, że system finansowania ochrony zdrowia powinien zapewniać środki na takim poziomie, aby umożliwiał ludności korzystanie z wszystkich potrzebnych usług zdrowotnych oraz zapewniał ochronę przed katastrofą finansową lub zubożeniem związanym z chorobą i koniecznością samodzielnego płacenia za usługi zdrowotne ${ }^{71}$. Współcześnie można wskazać takie źródła finansowania ochrony zdrowia, jak: budżet państwa, obowiązkowe ubezpieczenia, dobrowolne ubezpieczenia prywatne, opłata za usługę oraz dobroczynność. Niezależnie od przyjętego modelu finansowania pieniądze na ochronę zdrowia pochodzą zawsze od obywateli.

Warto podkreślić, że wydatki na zdrowie stanowią inwestycję w rozwój ludzki, pomyślność i dobrobyt. Lepsze zdrowie przyczynia się bowiem między innymi do aktywniejszego uczestnictwa w rynku pracy oraz rozwoju ekonomicznego. Mówiąc o efektywności finansowania ochrony zdrowia, wskazuje się jej dwa wymiary, tj. efektywność makroekonomiczną, czyli przeznaczanie na usługi medyczne takiej wielkości środków, która umożliwi zaspokojenie potrzeb zdrowotnych, nie naruszając równowagi ekonomicznej, oraz efektywność mikroekonomiczną, czyli uzyskiwanie najlepszych efektów zdrowotnych i zadowolenia pacjentów przy możliwie niskich kosztach ${ }^{72}$.

70 B. Zajaci in., „Posłuszeństwo” pacjentów związane z antybiotykoterapią na przykładzie wybranej grupy młodzieży i dorosłych, „Medycyna Ogólna i Nauki o Zdrowiu” 2014, nr 1, s. 1-5.

71 Everybody business: strengthening health systems to improve health outcomes: WHO's framework for action, WHO, 2007.

72 G. Magnuszewska-Otulak, Ochrona zdrowia w polityce społecznej [w:] Polityka społeczna, red. G. Firlit-Fesnak, M. Szylko-Skoczny, Warszawa 2007. 
W Polsce system ochrony zdrowia finansowany jest w głównej mierze z obowiązkowego ubezpieczenia zdrowotnego. Według danych OECD ubezpieczeniem zdrowotnym w 2015 r. objęte było 91\% populacji. Do tej grupy, zgodnie z przyjętymi regulacjami, należały osoby pracujące, obowiązkowo odprowadzające składki wraz z członkami ich rodzin, osoby dobrowolnie ubezpieczone, a także grupy osób, za które składki opłacane są z budżetu państwa. Fakt, że w 2015 r. 9\% populacji nie było objęte ubezpieczeniem zdrowotnym, częściowo wynikał z zawierania doraźnych lub nietypowych umów o pracę.

Wydatki na ochronę zdrowia liczone jako procent PKB wynosiły w Polsce w 2016 r. 6,4\% (wydatki publiczne 4,4\% PKB i wydatki prywatne 2,0\% PKB), co sytuowało nasz kraj poniżej średniej dla 35 państw OECD $(9,0 \%$, w tym wydatki publiczne 6,5\% i wydatki prywatne 2,5\%), a także poniżej wydatków państw naszego regionu, np. Niemiec (11,3\%), Węgier (7,6\%), Czech (7,3\%) i Słowacji $(6,9 \%)$. Wydatki na zdrowie w przeliczeniu na jednego mieszkańca, wynoszące 1798 dolarów US (według parytetu siły nabywczej), również były niższe od średniej OECD (4003 dolarów US) i wydatków Niemiec, Czech, Słowacji i Węgier (odpowiednio 5551, 2554, 2150 i 2101 dolarów US) ${ }^{73}$. Należy zwrócić uwagę na planowany stopniowy wzrost wydatków publicznych od 4,78\% PKB w 2018 r. do 6\% PKB w 2024 r. Wymóg corocznego wzrostu nakładów został zapisany w ustawie o świadczeniach opieki zdrowotnej finansowanych ze środków publicznych ${ }^{74}$.

Zgodnie z narodowym rachunkiem zdrowia ${ }^{75}$ w 2016 r. $^{76}$ z ogółu wydatków na zdrowie wydatki publiczne stanowiły 69,8\%. Najwięcej środków, tj. 59,8\% wydatków ogółem, stanowiły obowiązkowe ubezpieczenia zdrowotne oparte na składkach. Wydatki instytucji rządowych i samorządowych stanowiły 10,0\% wydatków ogółem. Udział wydatków prywatnych - głównie wydatków bezpośrednich, bo dobrowolne ubezpieczenia zdrowotne odgrywają rolę marginalną, wynosił 30,2\%. W strukturze wydatków w okresie 2013-2016 następowały zmiany, tj. udział wydatków publicznych zmniejszał się przy wzroście udziału wydatków prywatnych (tabela 8).

Udział wydatków prywatnych „bezpośrednio z kieszeni” (out-of-pocket) w 2015 r. na poziomie ok. 30\% wydatków na zdrowie był wyższy niż przeciętna

73 Health at a Glance 2017: OECD Indicators, op. cit.

${ }^{74}$ Art. 131c ustawy z 27 sierpnia 2004 r. o świadczeniach opieki zdrowotnej finansowanych ze środków publicznych.

${ }^{75}$ System rachunków zdrowia jest międzynarodowym narzędziem analizy wydatków na ochronę zdrowia, które ujmuje je w sposób wszechstronny, zapewniający porównywalność między krajami. Narodowe rachunki zdrowia umożliwiają systematyczny opis przepływów finansowych związanych z konsumpcją towarów i usług w zakresie opieki zdrowotnej. Ich celem jest opisanie systemu zdrowia z perspektywy wydatków. Od 2013 r. narodowy rachunek zdrowia prowadzony jest według zmienionej metodologii. W związku z tym trudno jest porównywać dane sprzed $2013 \mathrm{r}$. z danymi prezentowanymi po $2013 \mathrm{r}$.

${ }^{76}$ GUS, Narodowy rachunek zdrowia za 2016 r., Warszawa 2018. 


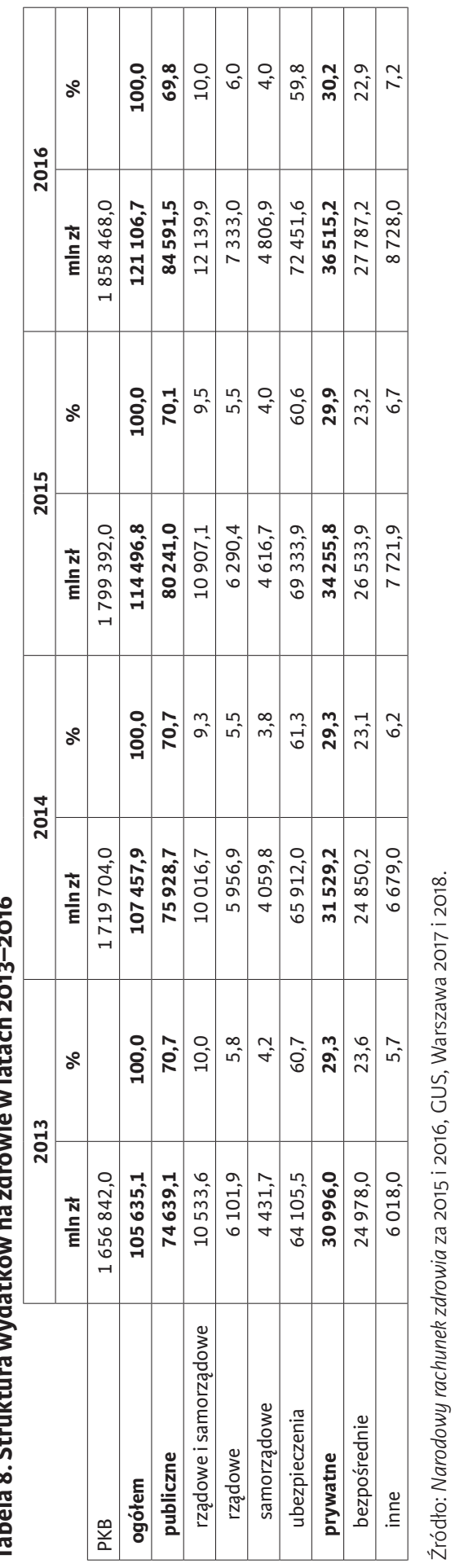


dla 24 państw UE, wynosząca (25,2\%), i wyraźnie odróżniał Polskę od takich krajów, jak Niemcy (15,4\%), Szwecja (16,1\%), Dania (16\%), Czechy (17,6\%), Słowacja $(20,2 \%)^{77}$. Zgodnie z danymi OECD w 2015 r. prywatne wydatki bezpośrednie w Polsce były przeznaczone głównie na produkty farmaceutyczne (59\% przy średniej OECD 31\%), a nie prywatne ubezpieczenia zdrowotne. Wynikało to w głównej mierze z niskiego poziomu refundacji leków, a także dużej popularności leków wydawanych bez recepty lekarskiej i względnie niskiego poziomu zamożności, niedającego podstaw dla upowszechniania dodatkowych ubezpieczeń prywatnych. Taka sytuacja może sprzyjać powiększaniu się występujących nierówności w dostępie do opieki zdrowotnej. Warto zwrócić uwagę, że możliwości przeznaczania środków prywatnych na zdrowie mogą zacząć maleć wraz ze zwiększaniem się w gronie osób pobierających emerytury odsetka osób otrzymujących świadczenia z tzw. nowego systemu emerytalnego, w którym stopa zastąpienia, tj. relacja pierwszej emerytury do ostatniej pensji, jest znacznie niższa niż w dotychczasowym systemie.

Jak wskazują szczegółowe badania budżetów gospodarstw domowych, w całej populacji ludności w Polsce średnie miesięczne wydatki na ochronę zdrowia na osobę wyniosły w 2016 r. 60,93 zł. Przeciętny członek gospodarstwa domowego mieszkającego w mieście wydał na ochronę zdrowia o 40,6\% więcej niż na wsi. Średnie miesięczne wydatki na ochronę zdrowia na osobę w gospodarstwach, w których przynajmniej jedna osoba korzystała z usług opieki zdrowotnej i które ponosiły na ten cel wydatki, wyniosły natomiast 582,56 zł. Dla tych wydatków różnica między ich średnim poziomem w gospodarstwach domowych na wsi oraz w miastach wynosiła 52,5\%. W strukturze wydatków „bezpośrednio z kieszeni” na ochronę zdrowia całej populacji zdecydowanie dominowały wydatki na leki, artykuły medyczne i medyczne dobra trwałego użytku $(69,2 \%)$. Udział wydatków out-of-pocket na stacjonarną opiekę zdrowotną wynosił $2,1 \%$, a na opiekę ambulatoryjną $28,7 \%{ }^{78}$.

W strukturze wydatków ze względu na funkcje w 2016 r. największy strumień wydatków bieżących na ochronę zdrowia skierowany był na usługi lecznicze. Wydatki te stanowiły średnio 57,3\%, w tym głównie na leczenie szpitalne i leczenie ambulatoryjne (średnio odpowiednio 31,5\% i 22,3\%). Udział wydatków na artykuły medyczne (między innymi leki) wynosił $23,2 \%$. Nakłady na opiekę długoterminową jako procent wydatków według funkcji wynosiły 5,8. Udział wydatków na usługi rehabilitacyjne oraz zarządzanie i administrację wynosił odpowiednio 3,4\% i 2,0\%. Zwracał uwagę niski udział wydatków na profilaktykę i zdrowie publiczne (2,8\% całości nakładów). W okresie 2013-2016 obserwowano malejący udział wydatków na artykuły medyczne oraz opiekę długoterminową. Należy zwrócić uwagę, że udział wydatków na profilaktykę i zdrowie publiczne wykazywał tendencję wzrostową.

77 Health at a Glance 2017: OECD Indicators, op. cit.

${ }^{78}$ GUS, Ochrona zdrowia w gospodarstwach domowych w 2016 r., op. cit., s. 73-74. 
Udział wydatków na leczenie szpitalne w Polsce (36\%) w 2015 r. był jednym z wyższych w krajach OECD (średnia 28\%). Wysoki udział wydatków na leczenie szpitalne może świadczyć o nadmiernym diagnozowaniu i leczeniu pacjentów w trybie hospitalizacji, a tym samym niedostatecznej roli ambulatoryjnej opieki zdrowotnej. Udział wydatków na leczenie ambulatoryjne był niższy (30\% przy średniej OECD 33\%). Jednocześnie wydatki na opiekę długoterminową należały do najniższych (6\% przy średniej dla OECD 14\%). Na tle krajów OECD w Polsce stosunkowo duży był udział wydatków na wyroby medyczne (23\% przy średniej OECD 19\%).

W strukturze wydatków ze względu na świadczeniodawców największy strumień środków w 2016 r. trafił do szpitali - 34,9\% kwoty wydatków bieżących na ochronę zdrowia. Były to głównie kwoty skierowane do szpitali ogólnych $32,2 \%$ wszystkich wydatków. Do placówek ambulatoryjnej opieki zdrowotnej trafiło 27,5\% środków, z kolei do sprzedawców detalicznych i innych dostawców dóbr medycznych 23,0\% (w tym głównie aptek - 20,7\%). Udział wydatków na stacjonarne zakłady opieki długoterminowej wynosił zaledwie 1,4\%. W okresie 2013-2016 obserwowano malejący udział kwot skierowanych do sprzedawców dóbr medycznych i wzrost udziału kwot dla placówek opieki ambulatoryjnej.

Obecnie funkcjonujący system finansowania zdrowia jest nadal niewystarczający dla zapewnienia kompleksowych, sprawiedliwych usług zdrowotnych o dobrej jakości dla ludności. Co istotne, ze względu na takie czynniki, jak postępujące starzenie się społeczeństwa, rozpowszechnienie chorób przewlekłych, wzrost kosztów technologii medycznych, komercjalizacja oraz rosnące oczekiwania ludności, należy spodziewać się, że w kolejnych latach wydatki na ochronę zdrowia będą rosły. Szacunki OECD wskazują, że o ile w okresie 2006-2010 wydatki publiczne na zdrowie wynosiły przeciętnie 6,2\% PKB [5,5\% opieka zdrowotna (OZ) i 0,8\% opieka długoterminowa (OD)], o tyle w perspektywie 2030 r. wzrosną w scenariuszu optymistycznym do 8,1\% (7,0\% OZ i $1,1 \% \mathrm{OD})$, a nawet $8,8 \%(7,5 \% \mathrm{OZ}$ i $1,3 \% \mathrm{OD})$ w scenariuszu pesymistycznym. Z kolei w 2060 r. osiągną 9,5\% (7,9\% OZ i 1,6\% OD) lub nawet 13,9\% (11,8\% OZ i $2,1 \%$ OD $)^{79}$.

Analizy wydatków na ochronę zdrowia skupiają się na wydatkach bezpośrednich, czyli tych związanych z podstawową opieką medyczną, opieką ambulatoryjną i stacjonarną, opieką doraźną, opieką długoterminową oraz kosztem leków. Jest to jednak tylko część kosztów - np. w chorobach nowotworowych wynosząca 36\% całościowych kosztów ekonomicznych. Inne koszty, jakie ponosimy jako społeczeństwo, to koszty związane z utraconą produktywnością, czyli utratą pracy zarobkowej pacjentów ze względu na ich stan (chorobę lub

79 J. Oliveira Martins, C. de la Maisonneuve, Public Spending on Health and Long-Term Care: a New Set of Projections, OECD 2013, https://doi.org/10.1787/2226583X [dostęp: 7 grudnia 2018 r.]. 
śmierć) - w chorobach nowotworowych odpowiadające za 43\% kosztów całościowych, a także opieka nieformalna, czyli koszty pracy opiekunów świadczących wsparcie dla pacjentów i koszty związane z utratą pracy nieodpłatnej (np. wolontariatu), które w przypadku chorób nowotworowych są szacowane na odpowiednio $14 \%$ i $7 \%$ kosztów całościowych ${ }^{80}$.

\section{Przywództwo i zarządzanie}

Zgodnie z ujęciem WHO przywództwo i zarządzanie obejmuje: tworzenie strategii działania i nadzór nad ich realizacją, budowanie porozumień i koalicji, tworzenie regulacji, zapewnienie systemów motywowania, monitorowanie funkcjonowania całego systemu, ewaluację, odpowiedzialność, współpracę międzysektorową. Przywództwo i zarządzanie ma w związku z tym podstawowe znaczenie dla funkcjonowania całego systemu ochrony zdrowia.

W Polsce planowanie polityki zdrowotnej w zasadniczym stopniu spoczywa na administracji rząadowej, wspieranej przez ekspertów oraz lekarzy - konsultantów krajowych w różnych dziedzinach medycyny. Główne prace planistyczne dotyczące zdrowia na szczeblu rządowym prowadzone są w Ministerstwie Zdrowia (polityka zdrowotna) oraz w Ministerstwie Finansów (poziom finansowania) ${ }^{81}$.

Minister Zdrowia jest naczelnym organem administracji rządowej właściwym w sprawach polityki zdrowotnej państwa. Minister kieruje działem administracji rządowej „Zdrowie”, jest dysponentem części 46 budżetu państwa. Obsługę Ministra zapewnia Ministerstwo Zdrowia ${ }^{82}$. Dział "Zdrowie” obejmuje sprawy:

- ochrony zdrowia i zasad organizacji opieki zdrowotnej,

- nadzoru nad produktami leczniczymi, wyrobami medycznymi, wyrobami medycznymi do diagnostyki in vitro, wyposażeniem wyrobów medycznych, wyposażeniem wyrobów medycznych do diagnostyki in vitro, aktywnymi wyrobami medycznymi do implantacji i produktami biobójczymi oraz nad kosmetykami w zakresie bezpieczeństwa i zdrowia ludzi,

- organizacji systemu Państwowe Ratownictwo Medyczne i nadzoru nad nim,

- zawodów medycznych,

- warunków sanitarnych i nadzoru sanitarnego, z wyłączeniem nadzoru nad żywnością objętego działem „Rolnictwo”, koordynacji bezpie-

80 All.Can: Poprawa efektywności i stabilności opieki onkologicznej. Rekomendacje dla Pol$s k i$, raport inicjatywy All.Can, marzec 2017, http://all-can.pl/wp-content/uploads/2017/03/ raport-All.Can-Rekomendacje-dla-Polski.pdf [dostęp: 1 września 2018 r.].

${ }^{81}$ Polska. Zarys systemu ochrony zdrowia, red. S. Golinowska, WHO, 2011, on behalf of the European Observatory on Health Systems and Policies, Warszawa 2012, s. 53-54.

${ }_{82}$ Rozporządzenie Prezesa Rady Ministrów z 10 stycznia 2018 r. w sprawie szczegółowego zakresu działania Ministra Zdrowia, Dz.U. poz. 95. 
czeństwa żywności, a w szczególności nadzoru nad jakością zdrowotną żywności w procesie produkcji i w obrocie oraz materiałami i wyrobami przeznaczonymi do kontaktu z żywnością,

- organizmów genetycznie zmodyfikowanych w zakresie wydawania decyzji zezwalających na wprowadzanie do obrotu nowej żywności oraz w zakresie wydawania zezwoleń na wprowadzanie do obrotu produktów leczniczych,

- lecznictwa uzdrowiskowego,

- koordynacji systemów zabezpieczenia społecznego w zakresie rzeczowych świadczeń leczniczych ${ }^{83}$.

Co więcej, Ministerstwo Zdrowia sprawuje nadzór nad Głównym Inspektorem Farmaceutycznym oraz Głównym Inspektorem Sanitarnym, Inspektorem do spraw Substancji Chemicznych, a także Prezesem Urzędu Rejestracji Produktów Leczniczych, Wyrobów Medycznych i Produktów Biobójczych. Podlega mu Agencja Rozwiązywania Problemów Alkoholowych. Lista jednostek podległych Ministrowi Zdrowia obejmuje 81 pozycji ${ }^{84}$. Nadzorem Ministra Zdrowia objęte są między innymi: instytuty naukowe, uczelnie medyczne, regionalne centra krwiodawstwa i krwiolecznictwa. Wśród szczególnie istotnych można wskazać między innymi Agencję Oceny Technologii Medycznych i Taryfikacji, Centrum Medyczne Kształcenia Podyplomowego, Narodowy Instytut Zdrowia Publicznego - Państwowy Zakład Higieny oraz Narodowy Fundusz Zdrowia (NFZ). Warto podkreślić, że Minister Zdrowia pełni kluczową funkcję jako koordynator zadań z zakresu zdrowia publicznego. Do obowiązków Ministra Zdrowia należy: przygotowanie projektu „Narodowego programu zdrowia”; monitorowanie realizacji zadań ustawowych oraz zapewnianie spójności zadań realizowanych przez wskazane do tego organy i podmioty ${ }^{85}$.

Szczególnie istotną rolę $\mathrm{w}$ polskim systemie ochrony zdrowia pełni Narodowy Fundusz Zdrowia, który ze środków pochodzących z obowiązkowych składek ubezpieczenia zdrowotnego finansuje świadczenia zdrowotne udzielane ubezpieczonym i refunduje leki. Zgodnie z ustawą z 27 sierpnia 2004 r. o świadczeniach opieki zdrowotnej finansowanych ze środków publicznych do zakresu działań NFZ należą również między innymi:

- określanie jakości i dostępności oraz analiza kosztów świadczeń opieki zdrowotnej w zakresie niezbędnym dla prawidłowego zawierania umów ze świadczeniodawcami o udzielanie świadczeń opieki zdrowotnej,

${ }^{83}$ Art. 43 ustawy z 4 września 1997 r. o działach administracji rządowej, t.j. Dz.U. 2018, poz. 762 , ze zm.

${ }^{84}$ Obwieszczenie Ministra Zdrowia z 4 grudnia 2017 r. w sprawie wykazu jednostek organizacyjnych podległych Ministrowi Zdrowia lub przez niego nadzorowanych, M.P. poz. 1157.

${ }^{85}$ Ustawa z 11 września 2015 r. o zdrowiu publicznym, t.j. Dz.U. 2018, poz. 1492. 
- przeprowadzanie konkursów ofert, rokowanie i zawieranie umów o udzielanie świadczeń opieki zdrowotnej, a także monitorowanie ich realizacji i rozliczanie,

- finansowanie świadczeń medycznych udzielanych świadczeniobiorcom innym niż ubezpieczeni spełniający kryterium dochodowe,

- opracowywanie, wdrażanie, realizowanie i finansowanie programów zdrowotnych,

- wykonywanie zadań zleconych, w tym finansowanych przez Ministerstwo Zdrowia, w szczególności realizacja programów zdrowotnych,

- monitorowanie ordynacji lekarskich,

- promocja zdrowia,

- prowadzenie Centralnego Wykazu Ubezpieczonych w celu potwierdzenia prawa pacjenta do bezpłatnych świadczeń zdrowotnych, gromadzenia danych o ubezpieczonych w NFZ,

- wydawanie poświadczeń i zaświadczeń w zakresie swojej działalności oraz rozliczania kosztów usług zdrowotnych,

- prowadzenie wydawniczej działalności promocyjnej i informacyjnej w zakresie ochrony zdrowia.

Działania prowadzone przez NFZ w istotnym stopniu kształtują system opieki zdrowotnej w Polsce. Niewielki zakres wykorzystania przez NFZ ocen jakości i efektywności przy finansowaniu świadczeń stanowi jedną z istotnych barier w poprawie funkcjonowania tego systemu.

\section{Podsumowanie}

Problemy polskiego systemu ochrony zdrowia dotykają wszystkich elementów składowych tego systemu, tj. zasobów kadrowych, dostarczania świadczeń zdrowotnych, systemu informacji zdrowotnej, dostępu do produktów i technologii medycznych, systemu finansowania oraz przywództwa i zarządzania. Występujące problemy sprawiają, że system nie działa we właściwy sposób, co znajduje odzwierciedlenie w niezależnych analizach międzynarodowych, jak np. Euro Health Consumer Index ${ }^{86}$.

Sytuacja zdrowotna populacji Polski w ciągu ostatnich dekad uległa wyraźnym zmianom. Wzrostowi przeciętnej długości życia towarzyszy zwiększenie liczby chorób przewlekłych ograniczających możliwości funkcjonowania i generujących zapotrzebowanie na świadczenia zdrowotne, a także niepokojąco duże nierówności w zdrowiu. Problemy te można jednak łagodzić przez odpowiednie działania z zakresu zdrowia publicznego. Wyzwaniem jest radykalna przemiana

86 Euro Health Consumer Index 2017, https://healthpowerhouse.com/media/EHCI-2017/ EHCI-2017-report.pdf [dostęp: 1 września 2018 r.]. 
struktury demograficznej społeczeństwa i wyraźny wzrost udziału osób starych w populacji, wraz ze spodziewanym pogorszeniem się ich sytuacji materialnej po zaprzestaniu aktywności zawodowej. Konieczne jest podjęcie działań ukierunkowanych na zapewnienie osobom starym możliwości jak najdłuższego samodzielnego funkcjonowania.

System ochrony zdrowia w Polsce charakteryzuje się poważnym deficytem pracowników. Jest to obecnie jedno z najbardziej istotnych wyzwań, jakie stoi przed państwem. Problem ten będzie się zaostrzał wraz ze starzeniem się społeczeństwa, co z kolei wygeneruje większe zapotrzebowanie na usługi medyczne. Poprawa sytuacji wymaga podjęcia kompleksowych działań obejmujących między innymi obszary szkolnictwa wyższego - szkolenie personelu oparte na rozpoznaniu potrzeb zdrowotnych społeczeństwa oraz wnikliwej analizie przesłanek przyznawania wysokich limitów przyjęć dla studentów niepolskojęzycznych ${ }^{87}$, poprawa warunków pracy i wynagrodzenia oraz zmiany organizacji pracy. Konieczne wydaje się angażowanie dodatkowych pracowników wspomagających pracę lekarzy i pielęgniarek. Nie bez znaczenia jest upowszechnienie zespołów interdyscyplinarnych - ze względu na przewlekły charakter coraz większej części problemów zdrowotnych pojawia się potrzeba powoływania zespołów składających się nie tylko z lekarzy i pielęgniarek, ale też psychologów, psychiatrów, dietetyków, rehabilitantów, fizjoterapeutów. W dalszej kolejności warto opracować całościową politykę kształcenia, motywowania i rozwoju zasobów ludzkich, obejmującą wszystkie zawody i specjalności niezbędne w systemie ochrony zdrowia.

Kwestia infrastruktury jest jedną z kluczowych dla funkcjonowania systemu ochrony zdrowia. Należy stwierdzić, że obecna infrastruktura systemu opieki zdrowotnej, w szczególności słabo rozwinięta podstawowa opieka zdrowotna, a także mała liczba zakładów opieki długoterminowej i łóżek opieki długoterminowej czy ich przestrzenne rozmieszczenie nie odpowiadają aktualnym potrzebom zdrowotnym populacji. Rozbudowana infrastruktura szpitalna wydaje się mało skuteczna w zakresie opieki i leczenia osób z chorobami przewlekłymi, w tym chorobami układu krążenia i nowotworami, a jest przy tym kosztowna w utrzymaniu. Odrębnym problemem jest również niedostateczna koordynacja pomiędzy jednostkami podstawowej opieki zdrowotnej, ambulatoryjnej opieki specjalistycznej oraz szpitalami. Dostęp do usług ochrony zdrowia w Polsce mimo przyjętych deklaracji nie jest powszechny. Największe problemy w uzyskaniu potrzebnych usług mają osoby o najniższym statusie społeczno-ekonomicznym. Poszukując alternatywnych rozwiązań, które pozwoliłyby ograniczyć

${ }^{87}$ Stanowisko nr 29/15/P-VII Prezydium Naczelnej Rady Lekarskiej z 17 czerwca 2015 r. w sprawie projektu rozporządzenia Ministra Zdrowia w sprawie limitu przyjęć na kierunki lekarski i lekarsko-dentystyczny, https://www.nil.org.pl/aktualnosci/stanowisko-prezydium-nrl-podjete-17-czerwca-br.?SQ_DESIGN_NAME=print [dostęp: 30 listopada 2018 r.]. 
wzrost wydatków na ochronę zdrowia, a także poprawić jej efektywność, zwraca się uwagę na konieczność rozwijania opieki środowiskowej i utrzymywania pacjentów jak najdłużej w ich środowisku rodzinnym, sąsiedzkim i domowym. Takim koncepcjom sprzyja rozwój technologiczny pozwalający w coraz większym stopniu usługi diagnostyczne i usługi lecznicze oddzielić od infrastruktury podmiotów opieki zdrowotnej.

Finansowanie systemu ochrony zdrowia w Polsce jest na poziomie niezadowalającym, wyraźnie niższym niż w wielu innych państwach europejskich. Zauważalny jest wysoki i rosnący udział wydatków prywatnych. Taka sytuacja ma wiele negatywnych konsekwencji, wśród których szczególnie niepokojące jest utrzymywanie się istotnych różnic w dostępie obywateli do zdrowia. Zapowiadane podwyższenie wydatków niekoniecznie doprowadzi do poprawy sytuacji, ponieważ koszty funkcjonowania systemów ochrony zdrowia stale rosną. Istotnym problemem jest brak dostatecznego uwzględniania jakości i efektywności świadczeń w decyzjach finansowych NFZ. Konieczne jest zwiększenie wydatków na działania z zakresu zdrowia publicznego.

Dostęp do leków i technologii medycznych w Polsce, mimo deklarowanego powszechnego i równego prawa do świadczeń opieki zdrowotnej finansowanej ze środków publicznych, jest poważnie zróżnicowany w zależności od dochodów, co wynika w głównej mierze ze stosunkowo niskiego poziomu refundacji leków. Problemem jest również brak odpowiednich działań władz publicznych ukierunkowanych na poprawę poziomu edukacji zdrowotnej obywateli.

Funkcjonujące w Polsce systemy informacji zdrowotnej pozostawiają wiele do życzenia. Prowadzony program informatyzacji daje nadzieję na poprawę sytuacji. Ocena realnej efektywność wypracowanych rozwiązań wymaga jednak czasu. W dalszym ciągu kompromitujący jest wysoki odsetek błędnie kodowanych przyczyn zgonów. Odrębną kwestią jest nikłe, w porównaniu z innymi państwami, wykorzystywanie nowoczesnych technologii teleinformatycznych.

Polski system ochrony zdrowia wymaga głębokich przekształceń. Optymalne kierunki zmian są wytyczone przez organizacje międzynarodowe. Do wprowadzenia zmian niezbędne jest jednak odpowiednie przywództwo, zarówno na poziomie centralnym, regionalnym, jak i w poszczególnych podmiotach systemu ochrony zdrowia.

\section{Bibliografia}

All.Can: Poprawa efektywności i stabilności opieki onkologicznej. Rekomendacje dla Polski, raport inicjatywy All.Can, marzec 2017, http://all-can.pl/wp-content/uploads/2017/03/raport-All.Can-Rekomendacje-dla-Polski.pdf.

A revolution in health care is coming, "The Economist” z 1 lutego $2018 \mathrm{r}$.

Bank Danych Lokalnych GUS, https://bdl.stat.gov.pl/BDL/start. 
Declaration of Astana, Global Conference on Primary Health Care From Alma-Ata towards universal health coverage and the Sustainable Development Goals Astana, Kazakhstan, 25 and 26 October 2018, https://www.who.int/docs/default-source/ primary-health/declaration/gcphc-declaration.pdf.

Diagnoza społeczna 2015. Warunki i jakość życia Polaków. Raport, red. J. Czapiński, T. Panek, Rada Monitoringu Społecznego, Warszawa 2015.

Euro Health Consumer Index 2017, https://healthpowerhouse.com/media/EHCI-2017/ EHCI-2017-report.pdf.

Everybody business: strengthening health systems to improve health outcomes: WHO's framework for action, WHO, 2007.

GUS, Narodowy rachunek zdrowia za 2016 r., Warszawa 2018.

GUS, Ochrona zdrowia w gospodarstwach domowych w 2016 r., Warszawa 2018.

GUS, Prognoza ludności na lata 2014-2050, Warszawa 2014.

GUS, Statystyka umieralności w wyniku chorób układu krążenia, Warszawa 2016.

GUS, Zdrowie i ochrona zdrowia w 2016 r., Warszawa 2017.

Health at a Glance 2017: OECD Indicators, OECD 2017, https://dx.doi.org/10.1787/ health_glance-2017-en.

Health at a Glance: Europe 2018: State of Health in the EU Cycle, OECD Publishing, Paris 2018, https://doi.org/10.1787/health_glance_eur-2018-en.

Kłos J., Gromadecka-Sutkiewicz M., Zysnarska M., Medykalizacja - wyzwanie XXI wie$k u$, „Hygeia Public Health” 2014, nr 49(3).

Kowalska K., Kalbarczyk W.P., Koordynowana opieka zdrowotna. Doświadczenia międzynarodowe, propozycje dla Polski, Warszawa 2013.

Leki dostępne bez recepty $i$ suplementy diety, komunikat $\mathrm{z}$ badań CBOS, nr 158/2016, Warszawa 2016.

Leowski J., Polityka zdrowotna a zdrowie publiczne, CeDeWu, Warszawa 2010.

Łanda K. i in., Fundusz Walki z Rakiem (FWR) propozycje rozwiazań systemowych, Kraków 2015, http://www.korektorzdrowia.pl/wp-content/uploads/fundusz-walki-z-rakiem-fwr-propozycje-rozwiazan-systemowych.pdf.

Magnuszewska-Otulak G., Ochrona zdrowia w polityce społecznej [w:] Polityka społeczna, red. G. Firlit-Fesnak, M. Szylko-Skoczny, Warszawa 2007.

Mahler H., The Meaning of „Health for All by the Year 2000”, „American Journal of Public Health" $2016 \mathrm{nr}$ 106(1), https://doi.org/10.2105/AJPH.2016.106136.

Monitoring the building blocks of health systems: a handbook of indicators and their measurement strategies, WHO, 2010.

NIK, „Kształcenie i przygotowanie zawodowe kadr medycznych”, informacja o wynikach kontroli, nr ewid. P/15/060, Warszawa 2016.

NIK, „Tworzenie map potrzeb zdrowotnych”, informacja o wynikach kontroli, nr ewid. 191/2017/P/17/059/KZD, Warszawa 2018.

NIK, „Zatrudnienie w samodzielnych publicznych zakładach opieki zdrowotnej”, informacja o wynikach kontroli, nr ewid. 41/2015/P/14/065/KZD, Warszawa 2015. 
OECD/European Observatory on Health Systems and Policies, Polska: Profil systemu ochrony zdrowia 2017, State of Health in the EU, OECD Publishing, Paris/European Observatory on Health Systems and Policies, Brussels 2017, https://dx.doi. org/10.1787/888933623533.

Oliveira Martins J., de la Maisonneuve C., Public Spending on Health and Long-Term Care: a New Set of Projections, OECD, 2013.

Opinie na temat funkcjonowania opieki zdrowotnej, komunikat z badań CBOS, nr 89/2018, Warszawa 2018.

Piotrowicz M., Cianciara D., Wysocki M.J., Systemy zdrowotne dla zdrowia i dobrobytuKarta $z$ Tallina, „Przegląd Epidemiologiczny” 2009, nr 63.

Polityka społeczna, red. G. Firlit-Fesnak, M. Szylko-Skoczny, Warszawa 2007.

Polska. Zarys systemu ochrony zdrowia, red. S. Golinowska, WHO, 2011, on behalf of the European Observatory on Health Systems and Policies, Warszawa 2012.

Prognoza kosztów świadczeń opieki zdrowotnej finansowanych przez Narodowy Fundusz Zdrowia w kontekście zmian demograficznych w Polsce, NFZ, Warszawa 2015.

Raport na temat zmian $w$ dostępności do gwarantowanych świadczeń zdrowotnych w Polsce $n$ r 18/27/06/2018, stan na kwiecień/maj 2018 r., http://www.korektorzdrowia.pl/ wp-content/uploads/barometrwhc_raport_062018.pdf.

„Rocznik Statystyczny Rzeczypospolitej Polskiej” 2017, GUS, i wcześniejsze.

Stanowisko nr 29/15/P-VII Prezydium Naczelnej Rady Lekarskiej z 17 czerwca 2015 r. w sprawie projektu rozporządzenia Ministra Zdrowia w sprawie limitu przyjęć na kierunki lekarski i lekarsko-dentystyczny, https://www.nil.org.pl/aktualnosci/stanowisko-prezydium-nrl-podjete-17-czerwca-br.?SQ_DESIGN_NAME=print.

Szukalski P., Jak umieraja Polacy?, „Demografia i Gerontologia Społeczna - Biuletyn Informacyjny” 2013, nr 1, http://dspace.uni.lodz.pl:8080/xmlui/bitstream/handle/11089/3565/2013-01\%20-\%20Jak\%20Polacy\%20umieraj\%C4\%85. pdf? sequence $=1$.

Sytuacja zdrowotna ludności w Polsce, http://www.sdgs.pl/wp-content/uploads/2017/06/ sytuacja-zdrowotna-ludnosci-w-polsce-2016-s.pdf.

Wojtczak A., Aktualne wyzwania zdrowotne społeczeństw, CeDeWu, Warszawa 2018.

Zajaci B. i in., „Posłuszeństwo” pacjentów związane z antybiotykoterapia na przykładzie wybranej grupy młodzieży i dorosłych, „Medycyna Ogólna i Nauki o Zdrowiu” 2014, nr 1.

\section{Akty prawne}

Ustawa z 4 września 1997 r. o działach administracji rządowej, t.j. Dz.U. 2018, poz. 762, ze zm.

Ustawa z 27 sierpnia 2004 r. o świadczeniach opieki zdrowotnej finansowanych ze środków publicznych, t.j. Dz.U. 2018, poz. 1510, ze zm.

Ustawa z 28 kwietnia 2011 r. o systemie informacji w ochronie zdrowia, t.j. Dz.U. 2017, poz. 1845 , ze zm.

Ustawa z 11 września 2015 r. o zdrowiu publicznym, t.j. Dz.U. 2018, poz. 1492. 
Obwieszczenie Ministra Zdrowia z 4 grudnia 2017 r. w sprawie wykazu jednostek organizacyjnych podległych Ministrowi Zdrowia lub przez niego nadzorowanych, M.P. poz. 1157.

Rozporządzenie Ministra Pracy i Polityki Społecznej z 7 sierpnia 2014 r. w sprawie klasyfikacji zawodów i specjalności na potrzeby rynku pracy oraz zakresu jej stosowania, Dz.U. 2018, poz. 227.

Rozporządzenie Prezesa Rady Ministrów z 10 stycznia 2018 r. w sprawie szczegółowego zakresu działania Ministra Zdrowia, Dz.U. poz. 95. 